\title{
Performing Colonial Modernity
}

\section{Fairs, Consumerism, and the Emergence of the Indonesian Middle Classes}

\author{
Arnout H.C. van der Meer* \\ Colby College \\ ahvander@colby.edu
}

\begin{abstract}
Late-colonial Indonesia witnessed the proliferation of annual fairs and exhibitions that attracted hundreds of thousands of visitors from all ethnic backgrounds and walks of life. This article argues that the Dutch colonizers organized these fairs as part of a larger hegemonic attempt to legitimize colonial authority. At the fairgrounds special exhibits demonstrated the benevolence of colonial governance, while modernity was displayed to emphasize the alleged cultural, technological, and scientific superiority of the West. Moreover, visitors were enticed to consume Western products and the lifestyles and world views associated with them. These fairs were mainly aimed at, and were constitutive of, the nascent Indonesian middle classes that became increasingly central to the maintenance of colonial rule. It is demonstrated that fairs were sites of interaction and discursive spaces where the middle classes not only bought into colonial discourse, but negotiated and challenged Western modernity to create a distinct, Indonesian middleclass lifestyle and culture.
\end{abstract}

\section{Keywords}

annual fairs - Pasar Gambir - consumerism - middle classes - colonial Indonesia cultural hegemony - modernity

* The research for this article was supported by an affiliated fellowship at the Royal Netherlands Institute of Southeast Asian and Caribbean Studies (KITLV) in Leiden, the Netherlands, and Colby College Social Science Grant 01.2263. I owe particular gratitude to Henk Schulte Nordholt and Tom Hoogervorst for their collaboration on this project, as well as to Michael Adas, Mary Beth Mills, and the two anonymous reviewers for their thoughtful comments on my paper. Finally, I would like to thank Hedwig van der Meer for her diligence in photographing many of the primary sources available in the Netherlands.

(C) ARNOUT H.C. VAN DER MEER, 2017 | DOI: 10.1163/22134379-17304015

This is an open access article distributed under the terms of the prevailing CC-BY-NC license at the time of publication. 


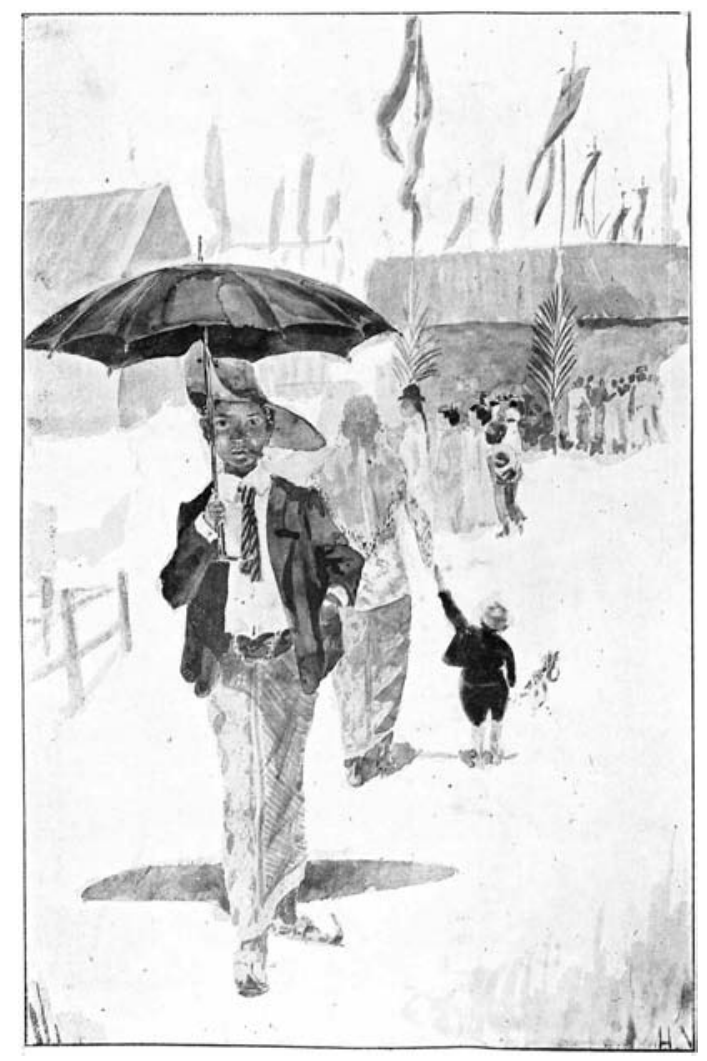

FIGURE 1 The modernized Javanese

WEEKBLAD VOOR INDIË, 16-6-19O7

In a popular weekly, a Dutch journalist described how at Surabaya's 1907 Jaarmarkt — the city's third annual trade and fun fair-Arabs, Chinese, Sundanese, Javanese, Madurese, Malays, Eurasians, and Europeans all promenaded the fairgrounds adorned in their best ethnic dress, seemingly in accordance with the colonial sartorial hierarchy. He was therefore startled to encounter several, what he called, 'modernized' or 'fake Javanese', who were partly clad in European clothes (Fig. 1). The columnist disdainfully described them as Pithecanthropus erectus (Eugène Dubois's 'Java Man') dressed-up with a brown slouch hat on their heads, a dress-shirt with a striped tie around their necks, a green waistband, black jacket and gold pocket watch, and a cheap payung (parasol). Only their sarong and smelly terompah (sandals) he deemed authentic. ${ }^{1}$ For

1 'Naar de Soerabajasche jaarmarkt-tentoonstelling', Weekblad voor Indië, 16-6-19o7. 
the author, the 'modernized Javanese' were out of place at the fairgrounds, as they subverted and blurred colonial hierarchies by not donning ethnic dress. Moreover, their presence ostensibly undermined the primary objective of the fair, which was to stimulate the indigenous artisanal industries and conserve traditional Javanese culture.

Unbeknownst to the European journalist of 1907, by the 1930s his 'modernized Javanese' would be omnipresent at the fairgrounds, which proliferated in twentieth-century colonial Indonesia to the point where every major city or town hosted its own fair, exhibition, or pasar malam (Indonesian night fair). This article argues that although the Dutch colonial regime used the organization of fairs to stage modernity and legitimize its authority (Coté 2006), the primarily indigenous visitors negotiated this attempt by shaping a distinct, middle-class lifestyle and identity in response. These large, physical sites of interaction attracted hundreds of thousands, if not millions, of people annually from different ethnic backgrounds and walks of life. And while these were far from egalitarian spaces, the fairs constituted a unique shared experience in the colonial world. They offered visitors the opportunity to experience modernity through their architecture, demonstration of tutelary strength, performances, entertainments, advertisements, and commercial displays. Moreover, they were spaces where visitors actively shaped their identities in relation to one another, colonial discourse, and modernity. In this context, the appearance of the 'modernized Javanese' at Surabaya's Jaarmarkt signified the emergence of the Indonesian middle classes and reveals the importance of fairs as massive sites of interaction and discursive spaces in the late-colonial world. As public spaces, fairs provided a forum for the negotiation of political, economic, and social anxieties that could not be directly communicated due to the realities of colonial inequality (Low 2000:201).

Given their scope and prominence in late-colonial society, it is remarkable that annual fairs have received scant attention from scholars of colonial Indonesia or colonialism in general-especially because developments in Indonesia were not isolated events: similar fairs emerged simultaneously throughout the colonial world, such as the Foire de Hanoi and the Manila Carnival. And while fairs have figured in several histories-for instance, on the performing arts - they were not the main focus of these studies (Cohen 2016:83-101; Keppy 2008:146-48). This has changed only recently, with publications by Yulia Nurliani Lukito on the hybrid architecture of the Pasar Gambir and the various ways in which it shaped the interaction between colonizer and colonized (Lukito 2015:77-103, 2016:17-68). The only other work that significantly addresses the proliferation of fairs, albeit indirectly, is that of Joost Coté on the 1914 colonial exhibition in Semarang, which was not an annual fair at 
all, but modelled after the world's fairs and exhibitions (Coté 2000:340-366, 2006:1-44). While at first glance the proliferation of annual fairs in the colonial world appears reminiscent of world and colonial exhibitions in the Western world, it is the very different nature of their location, intended audience, and objectives that sets them apart as a unique colonial phenomenon. The annual fairs were organized in Batavia, Hanoi, and Manila, rather than Amsterdam, Paris, and Washington; the colonized were the main audience rather than part of an ethnographic display; and modernity, rather than ethnographic traditions, was celebrated (for the world's fairs, see Bloembergen 2006; Morton 2003; Rydell 1984).

The annual fairs were important instruments in the modernizing and civilizing projects of the twentieth-century Dutch colonial state (Locher-Scholten 1981:176-208; Van Doorn 1994; Houben 2008:23-40). By employing Antonio Gramsci's concept of cultural hegemony, I show that this was very much a hegemonic project as well, but one that goes beyond Gramsci's emphasis on ideas by stressing the importance of material culture in the legitimization of the colonial regime (Van der Meer 2014:1-19; Gramsci 1971). With the advent of a civilizing discourse in the late nineteenth century, the legitimacy of the colonial state came to rely less on co-opting the Javanese aristocracy, and increasingly on the ability to modernize the Netherlands Indies and generate support among the nascent Indonesian middle classes. Within this context, fairs can be interpreted as stages on which modernity was performed and communicated. The architecture of the buildings, the design of the fairgrounds, the presence of a plethora of indigenous and Western merchandise, and the appearance of the visitors themselves were all part of the crucial decor. The juxtaposition between, on the one hand, Western merchandise, ranging from gas stoves and bicycles to the latest fashions and cigarettes, and on the other hand traditional Javanese batiks, wayang puppets, and gamelan instruments, was intentional. Here the Dutch colonizers presented themselves as developmental guides, harbingers of modernity, and developers of technological and scientific advantages demonstrating their supposed superiority and legitimizing their colonial domination. It was thus a performance in contrasts: the modern Dutch versus the backward Javanese (Van der Meer 2014:335-44).

This performance of colonial modernity at the fairs was specifically aimed at, and constitutive of, a nascent Indonesian middle class that had become gradually more central to the maintenance of colonial rule. As the contributions of Henk Schulte Northolt, Tom Hoogevorst, and Dafna Ruppin in this issue demonstrate, the rise of these middle classes coincided with the emergence of a new urban mass culture that was primarily visual, guided by advertisements, and illuminated by films. The fairgrounds incorporated all of these 
experiences into a single space, connecting the emergence of these urban middle classes with the hegemonic project of the state (Van Niel 1984; Schulte Nordholt 2011:435-57, 2015:223-54; Shiraishi 1990:27-40). Crucially, while the fairs were extremely popular, the nascent middle classes were not simply buying what the Dutch were selling. Like modernity itself, fairs were, as Vincent Houben pointed out, 'a discursive space [...] that was both empowering and unsettling' (Houben 2008:25; see also Colombijn and Coté 2015:1-28). At the fairgrounds the nascent Indonesian middle classes both embraced and contested colonial modernity, buying into certain elements while rejecting others. It was especially through consumer practices - of leisure, exhibits, food, and commodities - at the colonial fairs that a new middle-class identity and culture was shaped and performed. This new cultural space was characterized by a distinctive appearance, language, and morality, and by certain social practices, whereby attention was also given to gendered roles and responsibilities within this nascent middle-class culture. ${ }^{2}$

\section{Fairs as Civilizing Instruments}

The emergence of annual fairs coincided with the implementation of the Ethical Policy (1901), the Dutch equivalent of the French mission civilisatrice and the British 'white man's burden' that claimed to promote the development of the land and people of colonial Indonesia. In part, this was to be achieved through stimulation of the indigenous artisinal industries, which had suffered from the economic recession of the 189 os and the competition of Western imports. Of the various studies the colonial government commissioned on the condition of the artisinal industries, the first and most ambitious was conducted by J.H. Abendanon, director of the Departement van Onderwijs, Eeredienst en Nijverheid (Department of Education, Religion, and Industry) and a vocal advocate of the Ethical Policy. During a research tour of Java for his study in the spring of 1904, Abendanon proposed that the colonial authorities could improve the artisinal industries and, by extension, the welfare of the colonized through the organization of annual fairs. In his final report he explained how fairs would allow artisans access to larger markets to sell their products, gain a larger clientele, compare their work with that of others, and, as a result, improve their overall business opportunities. The report further suggested that

2 For non-Indonesian examples, see Burke 2012:468-74; Dutton 2012:21-42; Liechty 2003:1-7; and Joshi 20o1:1-22. 
by combining the exhibition of native arts and crafts with entertainment, a larger number of visitors could be attracted (Abendanon 1904: vol. I, 48-50 and vol. II, 247-55; Van Miert 1991:70-82). While the bulk of Abendanon's plans were deemed too radical and costly, his proposal regarding the organization of annual fairs was immediately adopted and became central to subsequent reports on how to counter the declining welfare of the indigenous population (Onderzoek 1909:12-4, 146-8; Onderzoek 1914:56-7).

The towns to premiere the organization of these combined trade fairs and funfairs were Batavia and Surabaya, where local authorities had committed to Abendanon's proposal during his tour of Java (Abendanon 1904:12-3, 217). Already in the summer of 1904, Batavia organized its first Pasar Gambir with the stated objective of 'promoting indigenous trade and industry' (Pleyte 1907:10). Surabaya followed suit with its Jaarmarkt (annual fair) in 1905, the official aim of which was to display indigenous craftsmanship and its products to those who were as yet unfamiliar with it, in order to create a larger market for indigenous artisans, and to encourage them to work more regularly (Jasper 1906). The authorities in both cities drew upon existing traditions in organizing these first annual fairs. In the colonial capital the initiative was taken by the association Oost en West (East and West), of which Abendanon himself was a founding member. This private association, known for its ethical propensities, combined its experience in organizing exhibits of indigenous arts and crafts (most recently in 1902) with the annual festivities on the Dutch Queen's birthday (31 August) and the Javanese tradition of night fairs (pasar malam), which were often held around special occasions (Bloembergen 2006:246-55; Cohen 2016:84-6; Van de Wall 1924). Similarly, in Surabaya, the local controller J.E. Jasper used his experience of putting together local arts and crafts exhibitions to organize the city's first fair around Hari Mulud, the celebration of the birthday of Muhammad (Kelling 1925:212-5). ${ }^{3}$

In accordance with Abendanon's proposal, Batavia's Pasar Gambir and Surabaya's Jaarmarkt focused primarily on the promotion of the artisinal industries. Local and regional artisans displayed their arts and crafts on stands at the fairgrounds. Both fairs also reserved large areas for live craft exhibits where artisans demonstrated their workmanship. In Batavia's kampong kerajinan (crafts village) and Surabaya's kampong tukang (artisan village) visitors could admire batik-painting, -stamping, and -waxing, woodworking, weaving, bamboo-plaiting, rattan-weaving, gold- and silversmithing, ivory-turning, horn-, bone-, and turtle-cutting, stone masonry, tanning, and pottery-firing. The

3 '34 jaren bij het Binnenlandsch Bestuur', Soerabaiasch Handelsblad, 8-6-1929. 
fairs further hosted a variety of traditional Javanese entertainments, including daily gamelan, wayang, and dance performances, to draw people to the exhibits. Interestingly, as these amusements by themselves did not attract enough people, the organizers added cinemas, sports (cycling and equestrian competitions), carousels, and stamboel (modern music and theatre performances). According to newspaper reports, these quickly turned into the main draws of the fairs (Jasper 1909; Pleyte 1907). ${ }^{4}$ Nonetheless, the organization of the fairs deliberately emphasized traditional Javanese culture, as defined by the selection of entertainments and exhibits by colonial experts. This reflected the paternal phase of the Ethical Policy that sought to develop, respect, and conserve indigenous culture under Dutch tutelage (Bloembergen 2006:223-5).

Western import companies and their modern products were conspicuously absent from these first fairs. This was not a coincidence, as the organizers intended to bolster the artisinal industries by excluding foreign competitors. According to contemporary reports by indigenous civil servants, the penetration of Java by Western imports had significantly impacted the lifestyle of the Javanese by the turn of the century. For instance, the bupati of Serang, Achmad Djajadiningrat-one of the principal organizers of the first Pasar Gambir, argued that the availability of affordable and reliable Western products created new desires and increased the cost of living. Specifically, it tempted people to consume conspicuously, as common Javanese tried to enhance their social status by imitating Europeans and the Javanese aristocracy. Among the products that were widely available at local markets were Swiss sarong and headscarves, silk slendang from Lyon, Swedish matches, perfumes, European clothing, jewellery, wristwatches, and canned food, such as Huntley and Palmer biscuits. By boycotting these products at the annual fairs the organizers sought to protect and stimulate the artisinal industries, for instance by encouraging the sale of payung (locally produced parasol) instead of European umbrellas, as well as to reduce conspicuous consumption. Taken together this would increase the prosperity of the indigenous population (Abendanon 1904, vol. I:14, 23; Onderzoek 1911:53-8).

The first annual fairs were thus complicated spaces in colonial Indonesia, exemplifying the tension in the Ethical discourse between the conservation of traditional culture - by way of stimulating the artisinal industries - and modern development-reflected in the modern amusements and access to Western products. Pulled in opposite directions, the fairs were a mixed success. While

4 'De jaarmarkt', Bataviaasch Nieuwsblad, 27-8-19o6; 'De Pasar Gambir', Het Nieuws van den Dag voor Nederlandsch-Indië, 26-8-1907. 
they drew large crowds, most people were drawn by the modern amusements, and less so by the exhibits and stands. Revealingly, in the same year (1908) that the Pasar Gambir drew a record-breaking 250,000 visitors in a period of less than two weeks, the organization had to cancel its kampong kerajinan due to budgetary problems. Instead, the fair reverted to merely offering entertainment around the Queen's anniversary. This is not to say that the stimulation of the artisinal industries was unsuccessful. According to reports about Surabaya's Jaarmarkt, the diversity, quality, and originality of the arts and crafts on display improved significantly between 1905 and 1908, which was reflected in a fourfold increase in the revenue from their sales (Jasper 1909). Surabaya's Jaarmarkt and its kampong tukang were more successful than Batavia's Pasar Gambir and organized until 1915. By that year, the First World War prevented any fairs from being organized for several years (Kelling 1925:210-2; Van Dijk 2007).

\section{Hegemony through Education and Entertainment}

The disruption in the organization of annual fairs due to the continuance and aftermath of the war in Europe allowed for reconsideration of their utility and purpose. The colony's precarious international position and the socioeconomic and political anxieties that permeated colonial society caused officialdom to reconsider its policies. With regards to the fairs, these anxieties resulted in a shift in focus from primarily promoting the indigenous artisinal industries to instigating broad modernization and industrialization of the colonial economy. Less emphasis would be placed on the conservation of Javanese culture and tradition and more on modern economic development (Dijkerman 1927:121-52; Kelling 1925:210-42). The first fair that exemplified this new approach was Bandung's Jaarbeurs in 1919. In the capital of the Priangan Residency local officials pushed for a European-style industrial fair (jaarbeurs) where importers, producers, local manufacturers, and retailers could come together. On the side, the organization added amusements and local artisans to attract more visitors. However, as Java was far from industrialized, for years Bandung's Jaarbeurs was an industrial fair in name alone. Instead, Western import companies, indigenous artisans, entertainments, and consumers came to dominate its fairgrounds (Jaarverslag 1929-1933; Reitsma 1927). ${ }^{5}$

Two more years passed before Batavia's Pasar Gambir was reinstated in 1921 (Programma 1922-1933). Its organizing committee had no intention of hosting

5 'Openingsrede Ten Damme, 17-9-1922', De Jaarbeurs, 15-1-1922. 


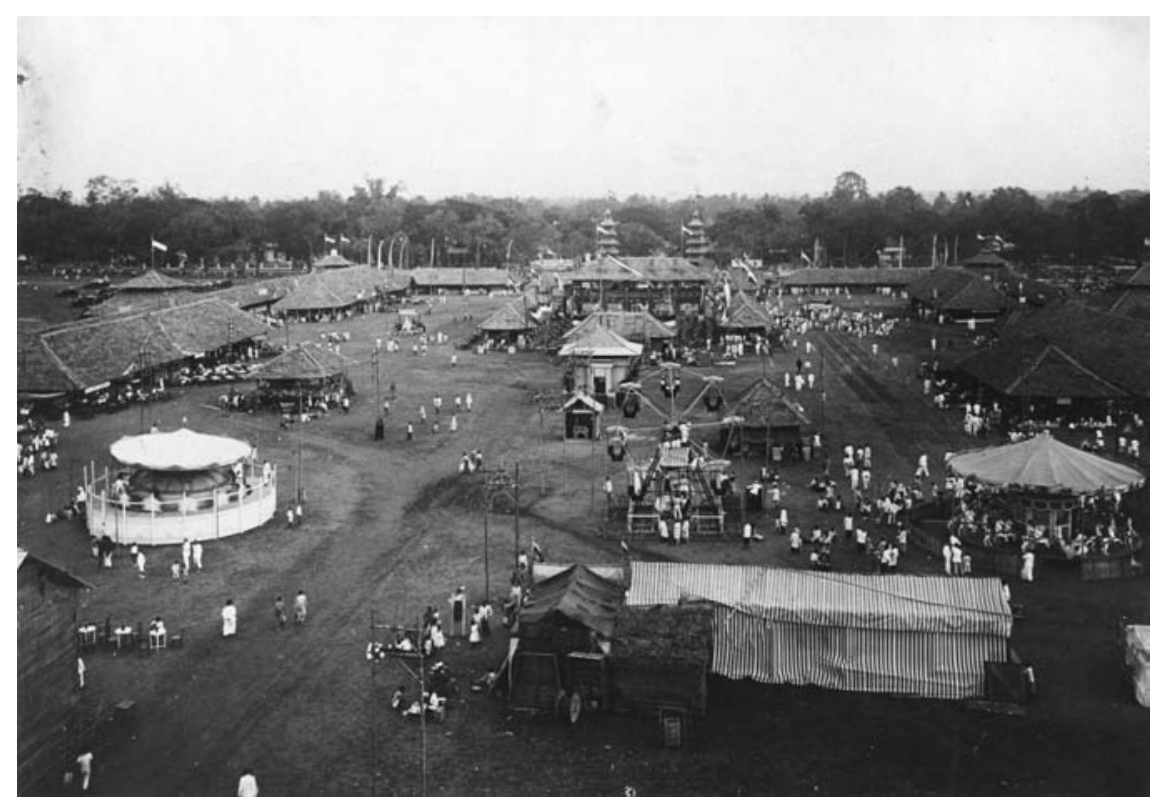

FIGURE 2 Pasar Gambir, 1922

LEIDEN UNIVERSITY, COLLECTIONS KITLV DIGITAL IMAGE LIBRARY

[UBL-KITLV], IMAGE CODE 1819 O

an industrial fair. While the stimulation of the artisinal industries remained its official objective, Western import companies dominated the fairgrounds (Fig. 2). Surabaya's restart of its Jaarbeurs in 1923 was highly contentious as it coincided with Bandung's Jaarbeurs. ${ }^{6}$ Moreover, Surabaya's committee proclaimed its city was much better situated to host an industrial fair, directly challenging the existence of its Bandung counterpart (Kelling 1925:226-39). ${ }^{7}$ These differences were resolved through government intervention, ensuring that Bandung - at least in name-remained the town with the only industrial fair and that Surabaya followed Batavia's model (Soerabaiaschejaarmarkt 19241931). To prevent inter-city competition, the Vereeniging ter Bevordering van het Jaarmarktwezen (Association for the Promotion of Annual Fairs) was founded in 1928 to coordinate the cycle of annual fairs: Bandung's Jaarbeurs in June, Batavia's Pasar Gambir in August, and Surabaya's Jaarmarkt in October. ${ }^{8}$ Due to

6 'De jaarmarkt', Indische Courant, 28-7-1923.

7 'Jaarbeurs en jaarmarkt', Indische Courant, 29-6-1923; 'De verhouding tusschen de Nederl. Ind. Jaarbeurs-Vereeniging te Bandoeng en de Jaarmarkt-Vereeniging te Soerabaia', De Jaarbeurs, 15-4-1923.

8 'Bevordering van het jaarmarktwezen in Indië', Indische Courant, 29-3-1928. 
its sheer size and plethora of vendors, advertising, food, amusements, sporting competitions, and exhibits, the Pasar Gambir established itself as Java's ultimate annual fair. It was renowned for its temporary bamboo and palm leaf buildings, which drew architectural inspiration from local, Asian, and Western styles. The resulting Oriental 'fairy-tale' pavilions were adorned with thousands of electric lights, which reflected the Dutch understanding of the colonial relationship: through following the enlightened example of the Dutch, the Javanese would, in time, be able to achieve modernity (Lukito 2016:17$68)$.

The changing character of the annual fairs in Java is best described in the writings of Simon Thomas, who as secretary of the local trade association served as a member on the Pasar Gambir organizational committee from 1922 to $1937 .{ }^{9}$ According to Simon Thomas, the new annual fairs intended to inform and civilize the indigenous population through the presentation of government programmes; create new consumer markets for Western-manufactured commodities; and strengthen colonial order. The extent to which these objectives could be realized depended on the ability of the organizing committees to attract visitors. Simon Thomas argued, similar to Abendanon before him, that entertainment was a crucial means to an end. People tended to flock to fairgrounds, not to exhibitions. The goal was to offer entertainment that would appeal to all members of colonial society (Simon Thomas 1928:1-4, 1929:117).

The pedagogical intentions of the annual fairs notwithstanding, most people visited annual fairs for their elaborate entertainments. While indigenous amusements had characterized the fairs before the First World War, their Western counterparts had predominated ever since. No fair was complete without cinemas, showing Hollywood's latest productions, and stages where one could listen or dance to Western music, varying from classical to jazz. Spectator sports and entertainments with a competitive character, for instance, for ballroom dances such as the foxtrot and waltz, car and motorcycle races, and sports (football, field hockey, baseball, and track and field events), were among the most popular attractions. The fairs offered another form of visual entertainment as well: the diorama and panorama. Popular subjects included Mecca during the Hajj, Jerusalem in the time of Christ, and the Battle of Waterloo. At the more exclusive restaurants visitors could also enjoy a treat that had been a rarity only a decade before-typical Dutch fare, such as pickled herring, rolmops (pickled herring rolled around a savoury filling), spekbokking (cold-smoked her-

9 'Dertig jaar in Indië in drie minuten', Bataviaasch Nieuwsblad, 11-6-1937. 


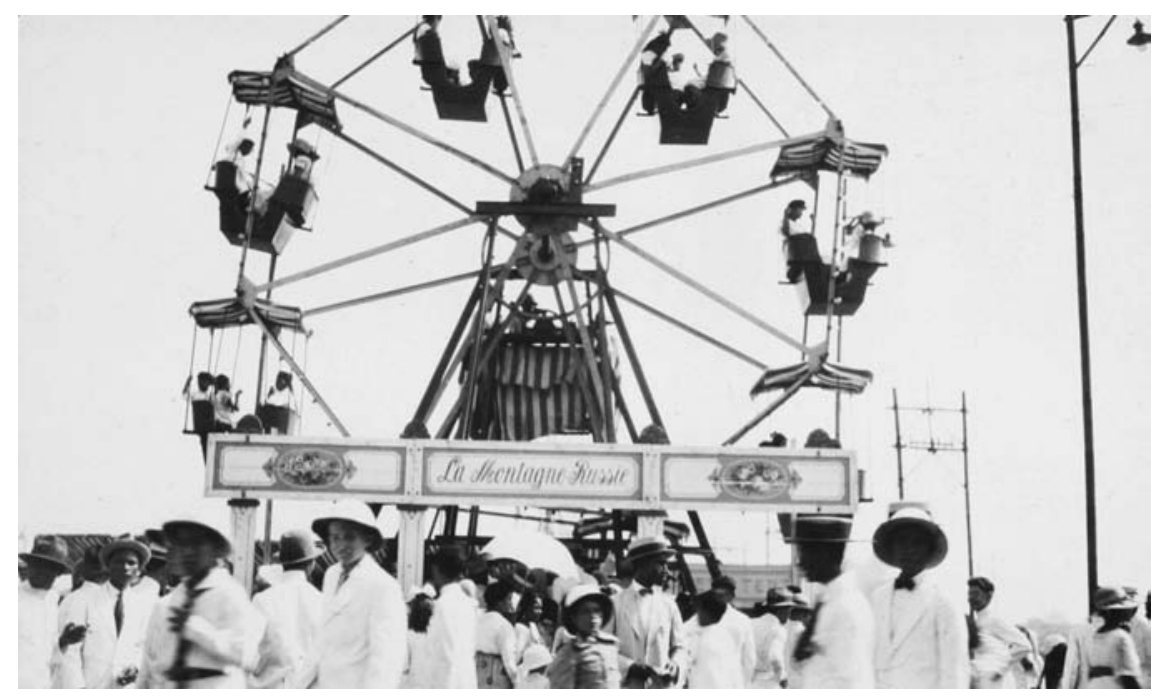

FIGURE 3 Ferris wheel and crowds at the Pasar Gambir, 1922 UBL-KITLV 13142

ring), mackerel, mussels, Russian salad, Dutch cold cuts, kroket (croquette), and sausage rolls (Programma 1922-1933).10

Many of the more popular attractions at Java's colonial fairs actually came from the Philippines. American entrepreneur Eddie Tait was the owner of the Manila Shows, with which he annually toured colonial Southeast Asia. The Manila Shows were famous for their mechanical attractions, such as various carousels, caterpillar rides, dodgems, and Ferris wheels (Fig. 3). In addition, visitors to Tait's shows could marvel at clowns, Mexican dancers, and performers with nicknames as 'the human fountain', 'the living skeleton', and 'Jolly Nelly' (a woman weighing 45 o pounds). Tait also brought hula-hula girls to Java, without whom, he once remarked, the Pasar Gambir would not be complete. The hulahula girls, dressed in nothing more than thatch skirts, a breast wrap, and some Hawaiian decorations, were amongst the most hotly debated draws at Java's fairs and the topic of many visitors' dreams. The success of Tait's Manila Shows as well as the organization of similar fairs in the Philippines and elsewhere in colonial Southeast Asia, suggests that there is also a larger regional trend that can be explored. ${ }^{11}$

\footnotetext{
10 See, for instance, descriptions in 'Pasar Gambir 1925', Pandji Poestaka, 25-8-1925 and 'Pasar Gambir 1936', Pandji Poestaka, 28-8-1936.

11 'De Luna Park czar van het Oosten', D'Oriënt, 24-9-1938.
} 
Whereas the mechanical rides and Western-style performances emphasized Western modernity, the indigenous entertainments and exhibitions were rooted in Java's past. Although these sections had become relatively small compared to their early-twentieth-century equivalents, all the major forms of indigenous craftsmanship could still be admired, such as batik and the creation of wayang puppets. In addition, several music (gamelan and angklung) and dance (ronggeng and topeng) performances occurred throughout the day (Programma 1923-1933). However, it should be remembered that the colonial fairs represented the indigenous peoples and their cultures as seen through the eyes of the colonizers. The contrast between on the one hand Western ice cream, jazz music, and Hollywood films, and on the other hand nasi goreng (fried rice), gamelan music, and wayang performances was intentionally produced. The implied message behind this contrast was straightforward: it signified to the indigenous observer what they were-primitive-and what they could become-modern (Van der Meer 2014:335-44).

By successfully drawing hundreds of thousands of visitors to Java's annual fairs with spectacular and diverse entertainments, the organizational committees effectively created large-scale sites of interaction where, according to Simon Thomas, the 'seemingly unnoticed and unintentional visual education' of the indigenous visitors could transpire (Simon Thomas 1929:7-8). The fairgrounds themselves, the architecture of the buildings, the many, visually engaging stands and exhibitions all served to convey the benevolence of Dutch colonial rule. The visual aspect was particularly important, since the majority of the visitors were not expected to be fully literate. These 'Ethical' goals remained embedded in the statutes of the primary fairs on Java, which all incorporated the promotion of indigenous agriculture, livestock, fishery, trade, and industry among their main objectives (Indisch Verslag 1931:221-2). To this end, various government agencies contributed exhibits to the fairs detailing their involvement in the development of indigenous arts and crafts, agricultural improvements, and the promotion of hygienic practices among the indigenous peoples (Programma 1923-1933; Jaarverslag 1929-1933).

Although they only occupied a small portion of the fairgrounds, the exhibitions of inheemse nijverheid (indigenous arts and crafts) were arguably the most important displays organized by the colonial government. At most fairs these exhibits were prepared by the Afdeeling Nijverheid (subdivision arts and crafts) of the Departement van Landbouw, Nijverheid en Handel (Department of Agriculture, Industry, and Trade). This government agency was specifically tasked with the promotion of indigenous arts and crafts and the creation of larger markets for the sale of its products (Indisch Verslag 1931-1937). The Afdeeling Nijverheid also played a crucial role in trying to improve the quality of the 
products, in effect pushing for some of these traditional items to be considered works of art. Another way in which these commodities were made more appealing was by tailoring them to European tastes and desires. For instance, they stimulated the production of batik tablecloths and pillowcases, leather fans, and wooden toys. ${ }^{12}$ At most fairs the exhibition of indigenous arts and crafts was still accompanied by an artisanal demonstration kampong. On the one hand this served as a pedagogical experience for all visitors, while on the other hand it had become a major tourist attraction. For many Europeans a visit to the artisanal kampong was a unique opportunity to familiarize themselves with indigenous culture, and many picked up a souvenir during their visit, such as a wayang puppet, a batik sarong, copper work, or a woodcarving.

Recurring exhibitions on hygiene and sanitation were a new addition to the annual fairs of the 1920 and 193os. Similar to the exhibits on indigenous arts and crafts, these were pedagogical expositions that both propagated the work of colonial agencies and demonstrated the Dutch commitment to the Ethical Policy. The hygienic exhibitions were organized by the Dienst der Volksgezondheid (Department of Public Health) and often included contributions from other health organizations, such as the Blindeninstituut (Institute for the Blind) in Bandung, the Institute Pasteur in Batavia, and local clinics and hospitals. At most fairs the hygienic exhibits were organized around an annual theme. For instance, Batavia's Pasar Gambir hosted exhibits that dealt with malaria, tuberculosis, the plague, eye disease, infant health and mortality, food preparation, drinking water, the danger of rats and flies, and first aid (Programma 1923-1933). Bandung's Jaarbeurs, which from 1924 onwards organized specialized, large exhibitions alongside its fair, hosted the Eerste Hygiënische Tentoonstelling in Nederlandsch-Indië (E HTINI, First Hygienic Exhibition in the Netherlands-Indies) in 1927. The main objective of the EHTINI-and all other hygienic exhibitions, for that matter-was to promote and disseminate among all strata of the populace knowledge of hygiene and its practical applications (Kelling 1927).

According to M.A.J. Kelling, secretary of the organizing committee of the EHTINI, the importance of this pedagogical task went beyond the improvement of physical health, by also reducing related mental weaknesses in the indigenous character that were the result of unsanitary living conditions, such as 'a lack of obstinacy, thrift, perseverance, and productivity' (Kelling 1927:63). Consequently, Kelling reasoned, since the majority of the indigenous audience

12 'Inlandsche kunstnijverheid', D'Oriënt, 30-8-1924; 'De Indische kunstnijverheid op den Pasar Gambir', D’Oriënt, 5-9-1925. 


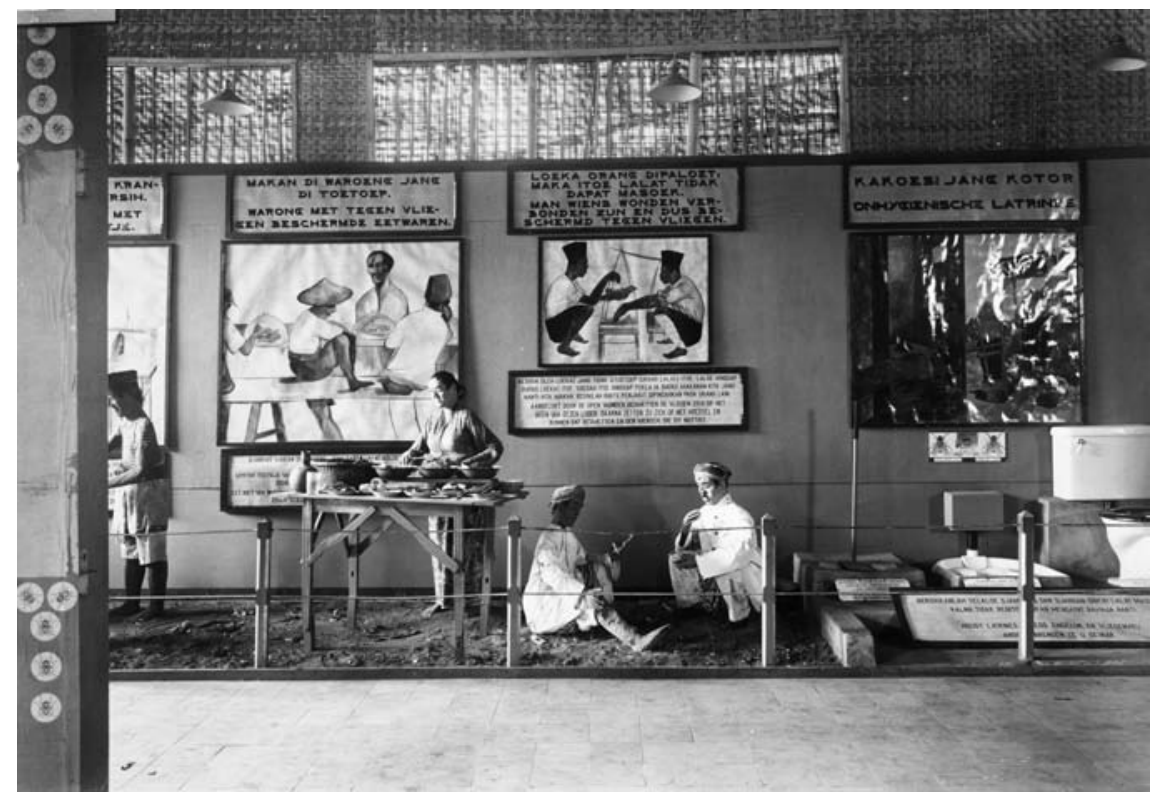

FIG URE 4 Stand of the Hygiene Committee at the Pasar Gambir, 1930

COLLECTION NATIONAAL MUSEUM VAN WERELDCULTUREN, OBJECT NR.

60012971

was still illiterate and mentally adapted to primitive living conditions, these exhibitions included very few tables, graphs, and statistics, but rather relied upon paintings, drawings, dioramas, and models to educate. For instance, at the Pasar Gambir of 1930 the health risk of the presence of flies was visually demonstrated through a contrast between dioramas that demonstrated unhygienic behaviour - uncovered food at a warung, open wounds, and filthy latrinesand paintings that showed the preferred hygienic alternative-covered food, dressed wounds, and clean latrines (Fig. 4).

In Kelling's opinion, the EHTINI disproved that annual fairs were primarily about economic and financial gains. Quite the opposite, he argued, as the Dutch took on the moral responsibility of educating the indigenous visitor about the benefits of Western science and hygienic practices. This had the added benefit, he believed, that 'whoever makes the people healthy, strengthens their rule' (Kelling 1927:63). The idea that promoting the civilizing work of the colonial government would stabilize colonial authority also lay behind the exhibits of other colonial agencies. For instance, the Bureau voor Volkslectuur or Balai Poestaka (the government agency that published informative literature for the indigenous population) provided visitors with informative pamphlets on a wide range of topics, such as how to purify water, personal hygiene, 
and the dangers of opium and alcohol addictions. Similarly, the exhibits of the Landbouwkundige Voorlichtingsdienst (Department of Agricultural Promotion) on agriculture, livestock, poultry, and horticulture informed visitors about the great strides that had been made and the further improvements that were possible by following Dutch advice and examples (Programma 19231933). ${ }^{13}$

\section{Fairs and the Creation of Desire}

While Simon Thomas claimed he greatly valued the pedagogical aspect of the annual fairs, he believed that their most important objective was 'the creation of new needs and desires' by familiarizing the indigenous masses with new commodities and expressions of Western culture (Simon Thomas 1928:4, 1929:9). The President of the annual fair in Surabaya, G.J. Dijkerman, voiced similar beliefs in stating that modern fairs distinguished themselves from traditional pasar malam by their focus on Western import companies and their commodities (Dijkerman 1927:127-32). However, creating demand for new, manufactured products among the largely illiterate indigenous population was no easy feat. Simon Thomas argued that advertisements in newspapers and periodicals and billboards were relatively expensive and ineffective means to reach Java's analphabetic masses. Instead, the millions of potential consumers needed to be convinced by product demonstrations. The experience of seeing, touching, trying, and, if applicable, tasting new commodities was crucial for the successful creation of desire among the Javanese. The annual fairs, Simon Thomas maintained, facilitated precisely these kinds of interactions between representatives of Western companies and the 'indigenous millions' (Simon Thomas 1929:9-11). ${ }^{14}$

While there were alternative ways in which the indigenous consumers could be reached, according to Simon Thomas none was more cost-efficient than the annual fairs. For instance, following the First World War the British American Tobacco Company (BATC) embarked on a large-scale sales campaign in Java. To create a market for its white cigarettes, as opposed to locally produced kretek (clove cigarettes), it sent salesmen and interpreters in Ford vans out into Java's countryside to hand out samples, sell cigarettes, and post advertising

\footnotetext{
13 'Pemboekaan Pasar Gambir', Pandji Poestaka, 1-9-1931 and 8-9-1931.

14 'De jaarmarkt', De Indische Courant, 12-10-1927; 'Hoe anderen den Pasar Gambir zien', Het Nieuws van den Dag voor Nederlandsch-Indië, 7-9-1929.
} 
materials. While it was a highly successful campaign for the BATC, which soon opened two factories in Java (in Cirebon in 1925 and Semarang in 1929), it was a costly promotional strategy that most could simply not afford. The annual fairs provided a viable alternative by bringing Western producers, importers, and indigenous consumers together. Similar to the BATC campaign, the fairs allowed for sensory marketing in which touch played a crucial role: it allowed potential consumers to create a symbolic connection and a sense of ownership over items that was simply absent in regular displays or advertisements (Cox 2000:279-83).

In their search for new, global growth markets, Western companies found that Java's colonial fairs were effective intermediary institutions in reaching millions of potential consumers. With the resumption of the fairs in the early 1920s, Western commercial interests quickly came to dominate the fairgrounds. For instance, in between 1925 and 1927, Western companies accounted for approximately $65 \%$ of the commercial stands at the Pasar Gambir. Of the remaining stands, Foreign Orientals (principally Chinese) rented out around $20 \%$ and indigenous entrepreneurs, $15 \% .^{15}$ The products on display ranged from luxury items intended for colonial elites to mass-produced commodities for mass consumption. One could thus find advanced forms of transportation, such as cars (Fiat, Ford, General Motors), motorcycles (Harley Davidson), and bicycles, but also electrical appliances for household convenience or leisure that included fridges (Kelvinator, Frigidaire), cameras (Kodak, Agfa), and gramophones and radio players (Edison, Philips, Columbia Records). The majority of the products were mass-produced commodities, such as products for personal hygiene and appearance (Colgate and Pepsodent toothpaste, Lux and Lifebuoy soaps, Cutex lipstick, and perfumes), medicines (Bayer, Lakeroll), food items (Blue Band, Droste cacao, Sun-Maid raisins, Coca-Cola, Victoria biscuits), alcoholic beverages (Amstel, Bavaria, and Heineken beer, Bols), tobacco products (British American Tobacco, Camel, Faroka, MacGillavry, Van Nelle), and shoes (Bata, Keds, and Jack) (Programma 1923-1933).

The fairgrounds were spaces in which there was aggressive advertising and competition between producers and importers in search of new markets (Simon Thomas 1929:17). The stands at the fairs were designed by the newly emerging advertising agencies, which created elaborate displays and stunning decorations that often included electrical lighting (Fig. 5). According to an Indonesian reporter for the Pandji Poestaka, this was the zaman reclame-

15 These percentages are rough indications based upon Programma 1925-1927. 


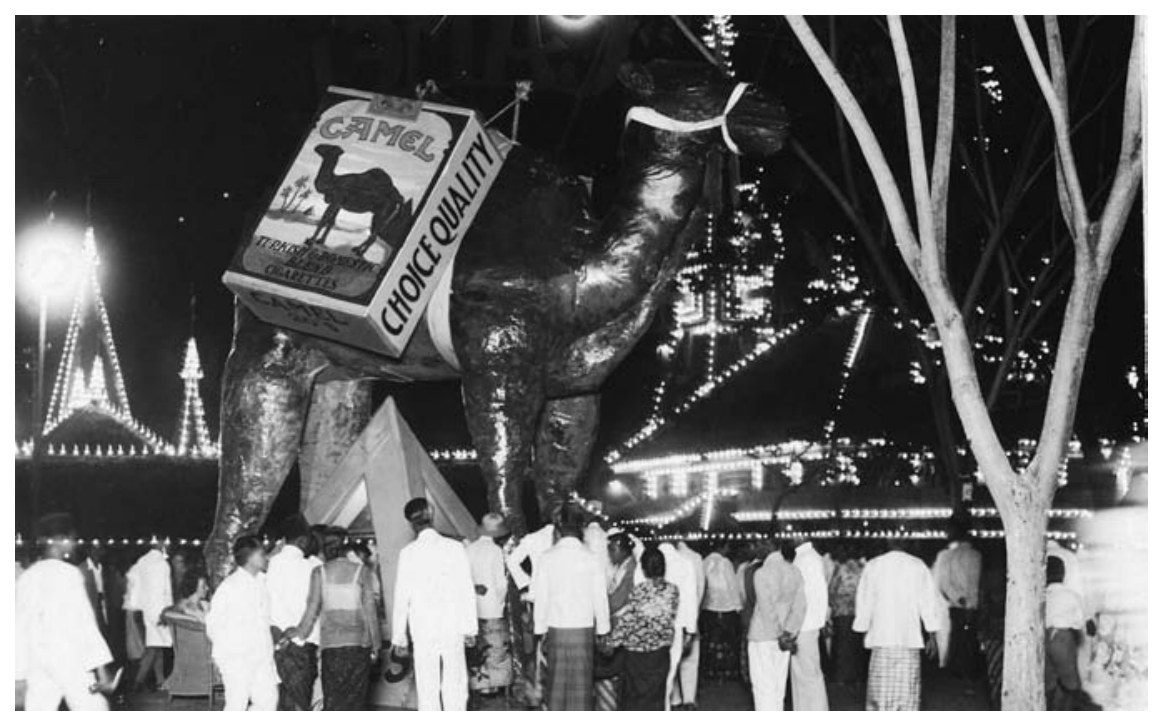

FIGURE 5 Camel cigarettes at the Pasar Gambir, 1930 UBL-KITLV 1658 o

'the age of advertising. ${ }^{16}$ In a time in which kampongs, villages, towns, islands, and countries were more interconnected than ever, he argued, a new space for commerce had opened up. Advertising at colonial fairs was a prerequisite for success, as it allowed producers to vie for the attention of potential customers through distinctive kiosks and stands. In 1925, the Pasar Gambir even organized a special exhibit on advertising in the colony. By providing several successful examples, the organization demonstrated how one could effectively advertise products or services. The annual fairs became famous for their spectacular advertising, which for many was an important part of their appeal. ${ }^{17}$

The broad variety of commodities, both in terms of price range and brands, at the colonial fairs presented nascent consumers with a new kind of experience: to shape their identities through their consumption choices. While the majority of the indigenous visitors would not have been able to purchase many products, let alone any of the luxury items on display, they could selectively purchase more affordable items depending on their discretionary income. In this way, consumption choices resulted in varying degrees of association with modernity. At the lower end of the spectrum, one could purchase locally produced, Japanese, or Chinese knock-offs of modern products such as soap,

\footnotetext{
16 'Pasar Gambir', Pandji Poestaka, 30-8-1929.

17 'Eerste Ned. Indische reclame tentoonstelling', D’Oriënt, 5-9-1925.
} 
shoes, and bicycles, which could be replaced with Western premium brands when financial fortunes improved. Consequently, consumption was not merely reflective of a new lifestyle, but also of one's social status (Liechty 2003:6-7, 31; Dutton 2012:21-42).

In pre-empting criticism that the commercial aspect of colonial fairs solely advanced Western business interests, Simon Thomas posited that the fairs had much to offer indigenous visitors as well. He acknowledged that the fairs, with their plethora of entertainments and enticing commercial character, were places where visitors could easily spend too much. However, as long as the pedagogical benefits outweighed the costs, he believed that this was acceptable. Alternatively, he reasoned, people would spend their money on less useful things or experiences. Instead, Simon Thomas assumed that conveying the important work of government agencies and creating new consumer needs would stimulate the indigenous population to work harder, earn more to satisfy those new desires, and consequently raise the prosperity of society as a whole. For Simon Thomas, and most of his contemporaries, the colonial fairs therefore did not merely fulfil an economic function, but also, and most importantly, a political one (Simon Thomas 1929:7-11).

The promotion of benevolent-ethical-policies and the creation of new consumer demands effectively encouraged indigenous visitors to buy into colonial modernity. The fairs were an essential part of the Dutch attempt, anchored in the Ethical Policy, to create a new form of cultural hegemony. This was a significant departure from colonial legitimization in the nineteenth century, which was constructed around collaboration with the Javanese traditional elite and relied on its aristocratic culture. In contrast, the Ethical Policy was aimed at the Western-educated elite and the growing number of Javanese participating directly in the modern colonial economy. It was believed that the 'consent' of these emerging elites and middle classes could not be gained through reference to a traditional past, but could instead be won by focusing on a cosmopolitan modernity (Van der Meer 2014:1-19). Consequently, the fairs, in a highly visual manner, contrasted Western modernity with Javanese backwardness in order to legitimize colonial authority. Through these fairs the Dutch demonstrated their technological and scientific prowess as indicators of their alleged superiority. However, high attendance and increased consumer consumption at the fairs did not mean the Javanese bought into modernity or colonialism. Instead, the fairs were spaces where the meaning of colonial modernity was very much contested.

The colonial fairs reflected the paradox of all civilizing discourses by inviting visitors to participate, seemingly as equals, in colonial modernity, while simultaneously reinforcing difference and social hierarchy. This was most clearly 
reflected in the differentiated entry fees. For instance, in 1925 the entry fees for Europeans, Foreign Orientals, and indigenous visitors at the Pasar Gambir were $f \circ .5 \circ, f \circ .25$, and $f \circ .15$ respectively (Programma 1925). All other major fairs, although with slightly different prices, instituted similar price differentiations. Colonial hierarchies were further reinforced once one entered the fairgrounds. For Europeans and non-Europeans there were segregated restrooms, dining facilities, movie theatres, parties (such as dances and ball masqués), and seating arrangements at sports events. Moreover, the sports events themselves were differentiated based on ethnicity as well, which meant, for instance, that there were segregated football tournaments each year. Although the situation was akin to an apartheid regime, the key difference was that segregation was not based on skin colour alone. An educated and affluent Javanese person clad in a European suit and fluent in Dutch could, if they wanted, attend most of the European entertainments. For instance, the report on the first annual fair in Semarang in 1908 bluntly stated that it did not prohibit indigenous people from dining at the European restaurant, but that they were required to pay an additional fee of $f$ o.10; the intention was that this would act as a deterrent to discourage them from eating there (Jasper 1911). The increased segregation of colonial society in general, and the fairs in particular, drew fierce criticism from the nationalist movement and vernacular press, which argued that the Dutch were 'whitening' the colonial elite. In 1925, the news that only Europeans were able to use a municipal swimming pool even caused the vernacular newspaper Hindia Baroe to call for a boycott—one which never transpired—of the Pasar Gambir. ${ }^{18}$

\section{Colonial Modernity, Middle Classes, and Conspicuous Consumption}

In 1929, an article in the Pandji Poestaka claimed that Batavia's Pasar Gambir and Surabaya's Jaarmarkt had become local traditions similar in stature to the Sekaten celebrations in Yogyakarta and Surakarta commemorating the birthday of the Prophet Muhammad. While this comparison underestimated the religious significance of the Sekaten celebrations, the massive crowds and positive attention in the press confirm that fairs had indeed become seemingly indispensable institutions in colonial society. In trying to explain the appeal of the post-war modernized fairs, one author sketched how visitors at the

18 Overzicht van de Inlandsche Pers (IPO) 1925-2, referring to Hindia Baroe, 20-5-1925. 
Pasar Gambir were struck by the 'bright electric lights, colourful flags and paper decorations, advertising, shouts of artisans and vendors, food stands, entertainments, and the crowds.. ${ }^{19}$ They came, he argued, to enjoy themselves, attend performances and other entertainments, but also for flyers and free commercial samples, such as tea, biscuits, and cigarettes, and of course to eat and drink. The fairs, in other words, facilitated a sensory exploration of modern life through its spectacular design of pavilions and stands, the omnipresent sounds of performances and crowds, the smells and tastes of diverse food offerings, and the ability to try unfamiliar commodities. Without naming it, the author's description suggests that people flocked to the fairs to experience what might be called colonial modernity and the activities associated with it, such as consumerism. ${ }^{20}$

The fairgrounds themselves were arguably the greatest attraction of Java's colonial fairs. Their architecture, layout, and design often differed greatly from one city to another-ranging from Batavia's temporary bamboo and thatch hybrid-oriental style, and Surabaya's semi-permanent entry pavilion inspired by a ship's bow, to Bandung's permanent modern exhibition halls — but all were clearly recognizable as contemporary and modern spaces (Lukito 2016:17-68). Not least, this was due to the extensive use of electric lighting for decorative purposes. At the Pasar Gambir the testing of the lights prior to its opening alone drew thousands of visitors. More than anything else, electric lights and appliances were associated with the modernity on display at the fairs. Not surprisingly, the lights were not only used for decorative, but also for advertising purposes. A striking example is an electric billboard of the cigarette company Mac Gillavry (Fig. 6). The billboard showed a well-dressed man smoking a cigarette; each time the man exhaled, consecutive lights created the illusion of smoke in the shape of the brand name Mac Gillavry. ${ }^{21}$ This billboard, like the elaborate designs of commercial stands, was a must-see for the fairs' visitors.

From a search of European and Indonesian sources it quickly becomes evident that one of the defining features of the modern experience at the fairs was the large, ethnically diverse crowds. For instance, in a letter to a friend, a Dutch schoolteacher explained how at Batavia's fair visitors from all ethnic backgrounds mixed in the crowds, while a Javanese journalist similarly

\footnotetext{
19 'Pasar Gambir', Pandji Poestaka, 30-8-1929.

20 Also see 'Pasar Gambir 1930', Pandji Poestaka, 5-9-193o and 'Berdjalan-djalan kekota bamboe: Pasar Gambir', Pandji Poestaka, 30-7-1937.

21 'Electrische lichtreclame', D'Oriënt, 4-9-1926.
} 


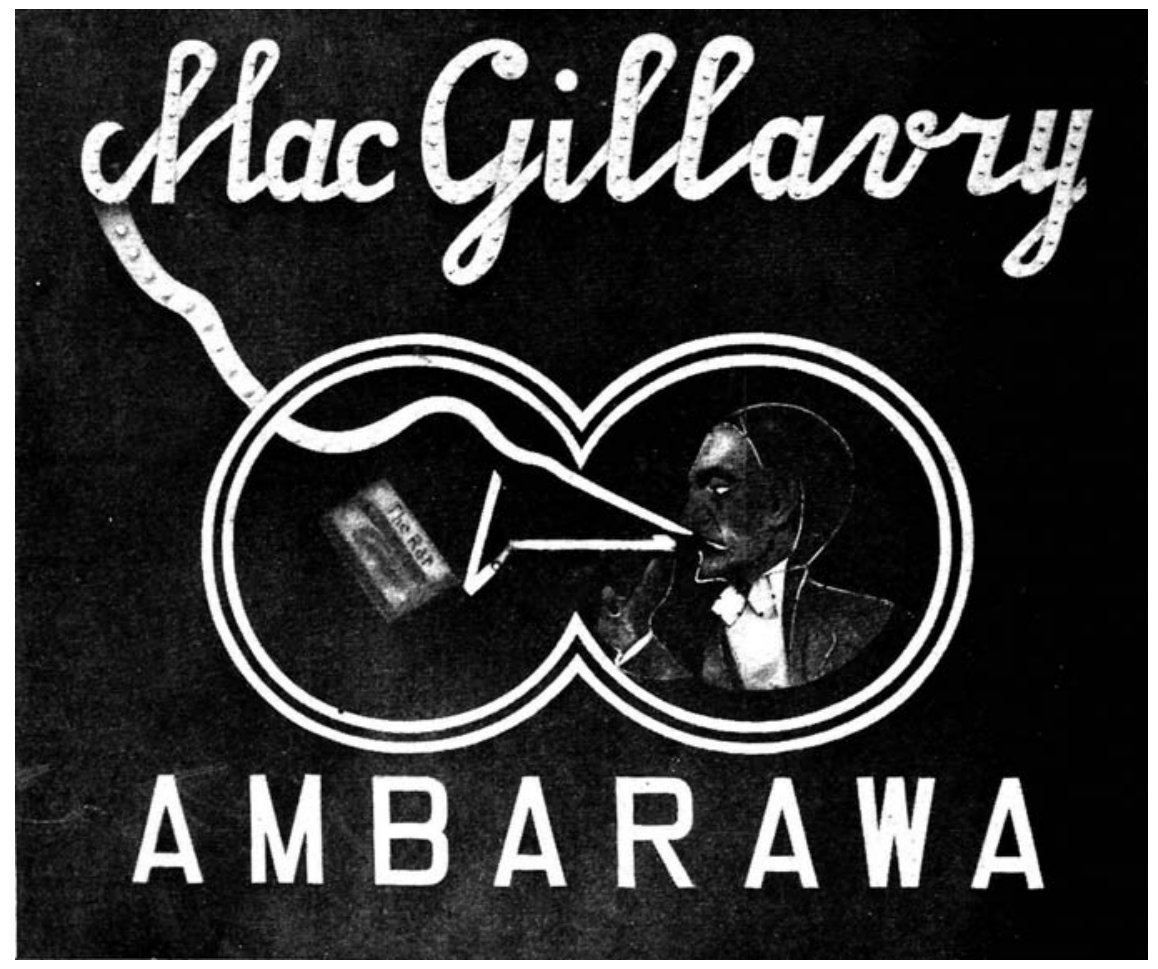

FIGURE 6 Mac Gillavry cigarettes electric billboard D'ORIËNT, 4-9-1926

described how 'all categories of our society meet at the Pasar Gambir'.22 The significance of these remarks is captured in figures 7 and 8 , which respectively show the total ticket sales (not unique visitors) of the three largest fairs and a breakdown of ticket sales by legal (ethnic) category for Batavia's Pasar Gambir. The statistics are especially impressive given that the fairs only lasted around two weeks (Batavia 13 days, Bandung and Surabaya 16 days). As many other towns organized fairs as well, it can be assumed that more than a million people visited them annually. In the case of the Pasar Gambir, between 1921 and 1939, $18 \%$ of these visitors were European, $23 \%$ Foreign Oriental, and an impressive $59 \%$ indigenous. ${ }^{23}$ Surprisingly, this meant that the indigenous population was

22 Letter F. van der Kooi to A.A. Cense, Leiden University Library Special Collections, Collection A.A. Cense, D OR. 545-305; 'Pasar Gambir', Pandji Poestaka, 29-7-1932.

23 At provincial fairs the proportion of indigenous visitors was even larger than in the major cities. For instance, of the 134,993 visitors to Pekalongan's 1924 Pasar Malam only $2 \%$ was European, 8\% Foreign Oriental, and 9o \% indigenous (Jasper 1924). 


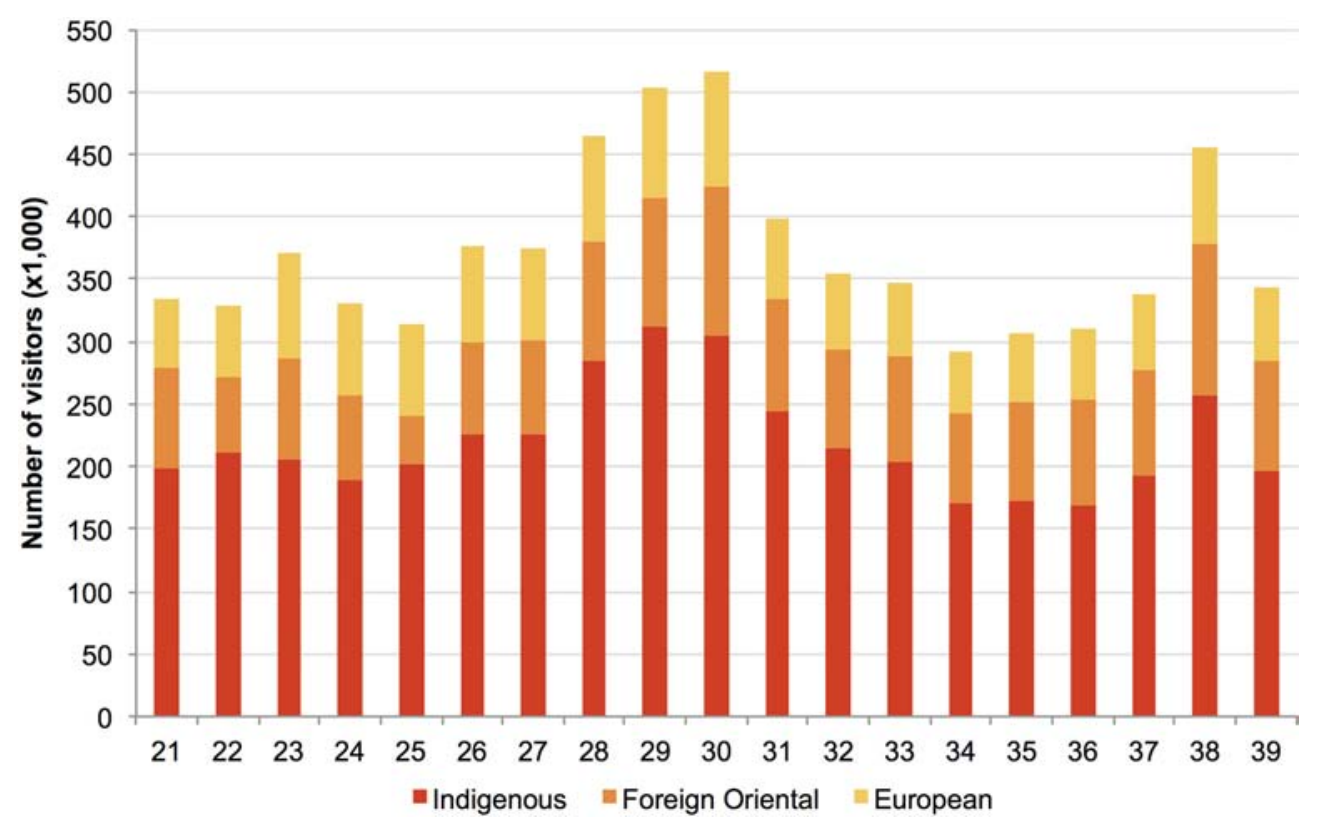

FIGURE 7 Pasar Gambir's visitors by legal (ethnic) category (1921-1939) DE PASAR GAMBIR 1932; JAARVERSLAG 1934; INDISCH VERSLAG 1939:233-4; BATAVIAASCH NIEUWSBLAD, 9-1-1924, 7-9-1933, AND 14-9-1934; DE SUMATRA POST, 10-9-1935 AND 12-9-1938; HET NIEUWS VAN DEN DAG VOOR NEDERLANDSCH-INDI ̈̈; 11-10-1927, 16-7-1936, 8-9-1936, AND 7-9-1939; DE INDISCHE COURANT, 13-10-1936, 18-7-1939, AND 12-10-1939; SOERABAIJASCH HANDELSBLAD, 18-10-1929; VAN DER ENG 1992:366-70.

underrepresented, as Europeans made up $7 \%$ of Batavia's populace, Foreign Orientals $16 \%$, and indigenous peoples $77 \%$.

The ticket sales only partially reflected the multitudes attracted by the fairgrounds. According to the European and indigenous press, the roads leading towards the fairs were littered with street vendors selling food, drinks, toys, fabrics, and more (Fig. 9). The temporary fairs thus created economic opportunities for salesmen and -women, retailers, and peddlers, who could either not afford or opted not to rent stands at the official fairgrounds. ${ }^{24}$ According to a European journalist, for 'people for whom a dime is a fortune' (the entry fare for indigenous peoples) these stands outside the fairgrounds were an opportunity to experience the excitement, marvel at the spectacular buildings draped in electric lights, listen to distant musical performances, and watch the fireworks

24 'Pasar Gambir ke-12', Pandji Poestaka, 6-9-1932. 


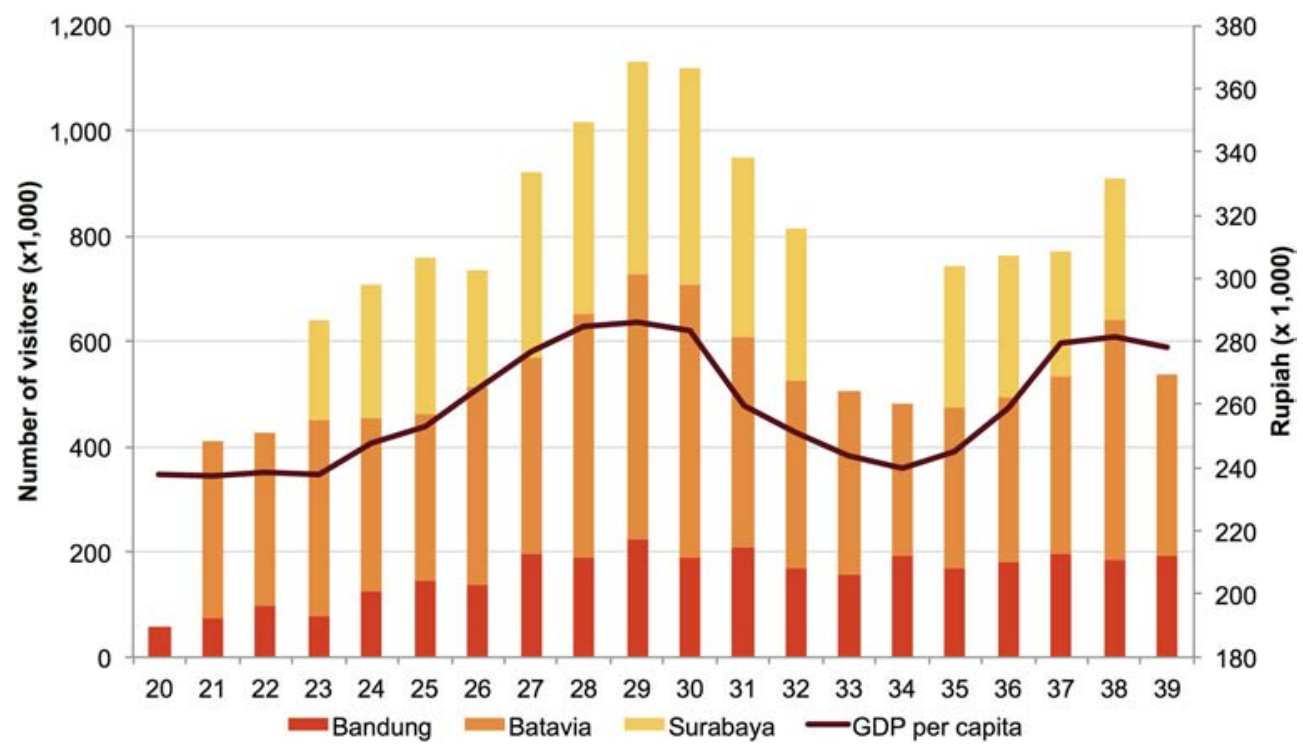

FIGURE 8 Visitors to Java's largest fairs and GDP per capita (1920-1939)

DE PASAR GAMBIR 1932; JAARVERSLAG 1934; INDISCH VERSLAG 1939:233-4; BATAVIAASCH NIEUWSBLAD, 9-1-1924, 7-9-1933, AND 14-9-1934; DE SUMATRA POST, 10-9-1935 AND 12-9-1938; HET NIEUWS VAN DEN DAG VOOR NEDERLANDSCH-INDIË; 11-10-1927, 16-7-1936, 8-9-1936, AND 7-9-1939; DE INDISCHE COURANT, 13-10-1936, 18-7-1939, AND 12-10-1939; SOERABAIJASCH HANDELSBLAD, 18-10-1929; VAN DER ENG 1992:366-70.

at night. ${ }^{25}$ The attempts by the less privileged to try to sneak or peek into the fairgrounds were popular themes of cartoons in Pandji Poestaka (Fig. 10), which once again suggests that the fairgrounds were only for those who could afford them.

Both figures demonstrate how the ticket sales of the fairs mirrored the development of the national and global economy. The fairs expanded with the economic recovery beginning in 1924, contracted with the Great Depression that impacted the Netherlands Indies especially from 1931 to 1934, and slowly grew again from 1935 until 1938, after which the prospect of war in Europe brought an end to the fairs, even before the Japanese occupation in 1942. The eerie similarity of this curve to the development of the gross domestic product (GDP) per capita in the Netherlands Indies during this period seems indicative of the consumer character of the fairs. When GDP per capita and, with it,

25 'Pasar Gambir te Batavia', Algemeen Handelsblad, 17-9-1935. 


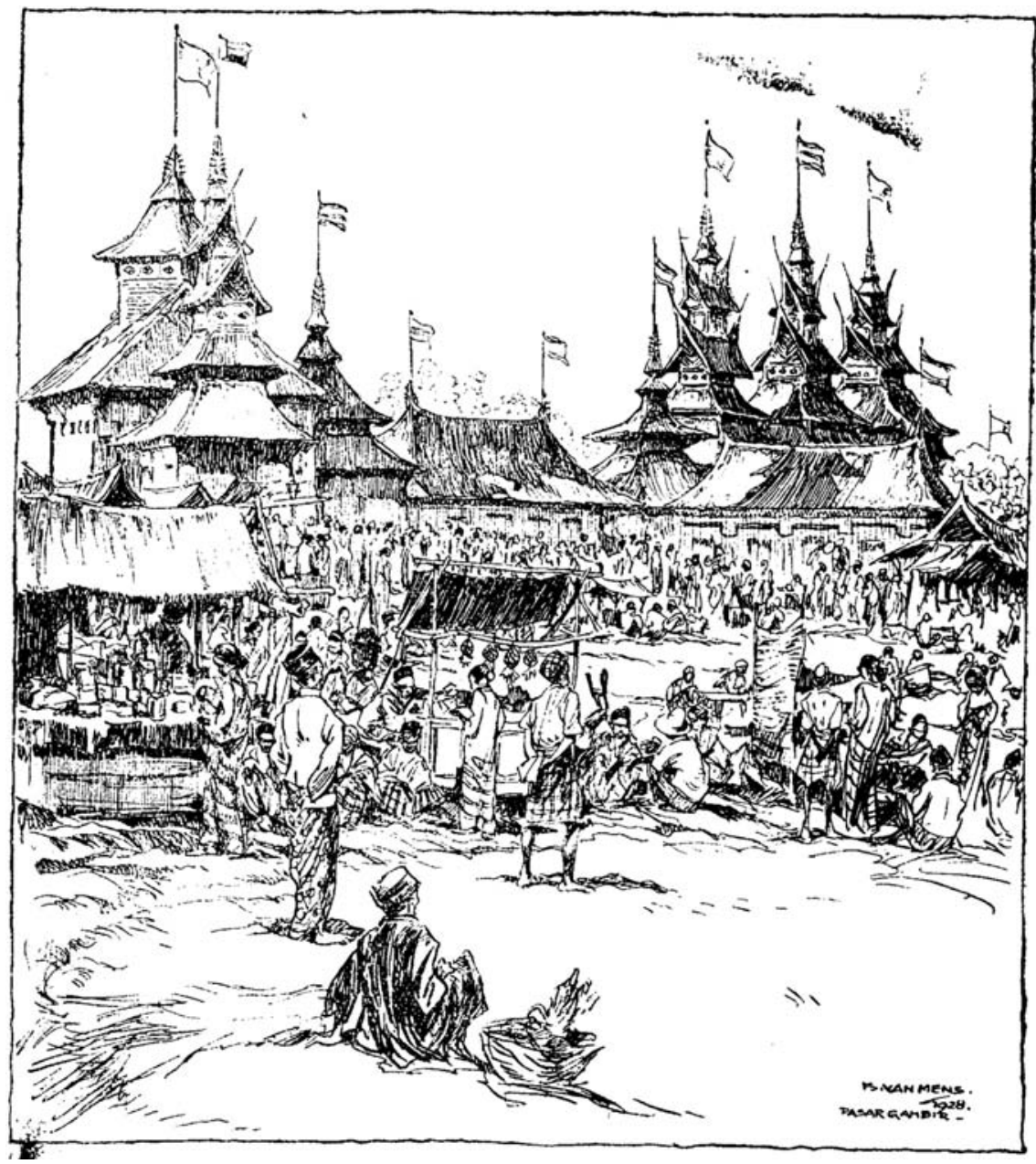

FIGURE 9 Crowds outside Pasar Gambir's fairgrounds NIEUWS VAN DEN DAG VOOR NEDERLANDSCH-INDIË, 3-9-1928

discretionary income, increased or decreased, this was reflected in consumer practices and fair attendance (Dick 2002:6; Van der Eng 1992:366-70).

These statistics suggest that visitors to Java's colonial fairs consisted primarily of those with discretionary income and an interest in consumer practices. In other words, these were people who were not simply interested in modern experiences, but could actually afford them. This most certainly did not mean that the fairs were only for the wealthy, as they allowed for several levels of engagement, from watching from the outside or paying the entrance fee merely to stroll around the fairgrounds, to more extensive consumption patterns involving entertainments requiring additional fees, to luxurious dining. 

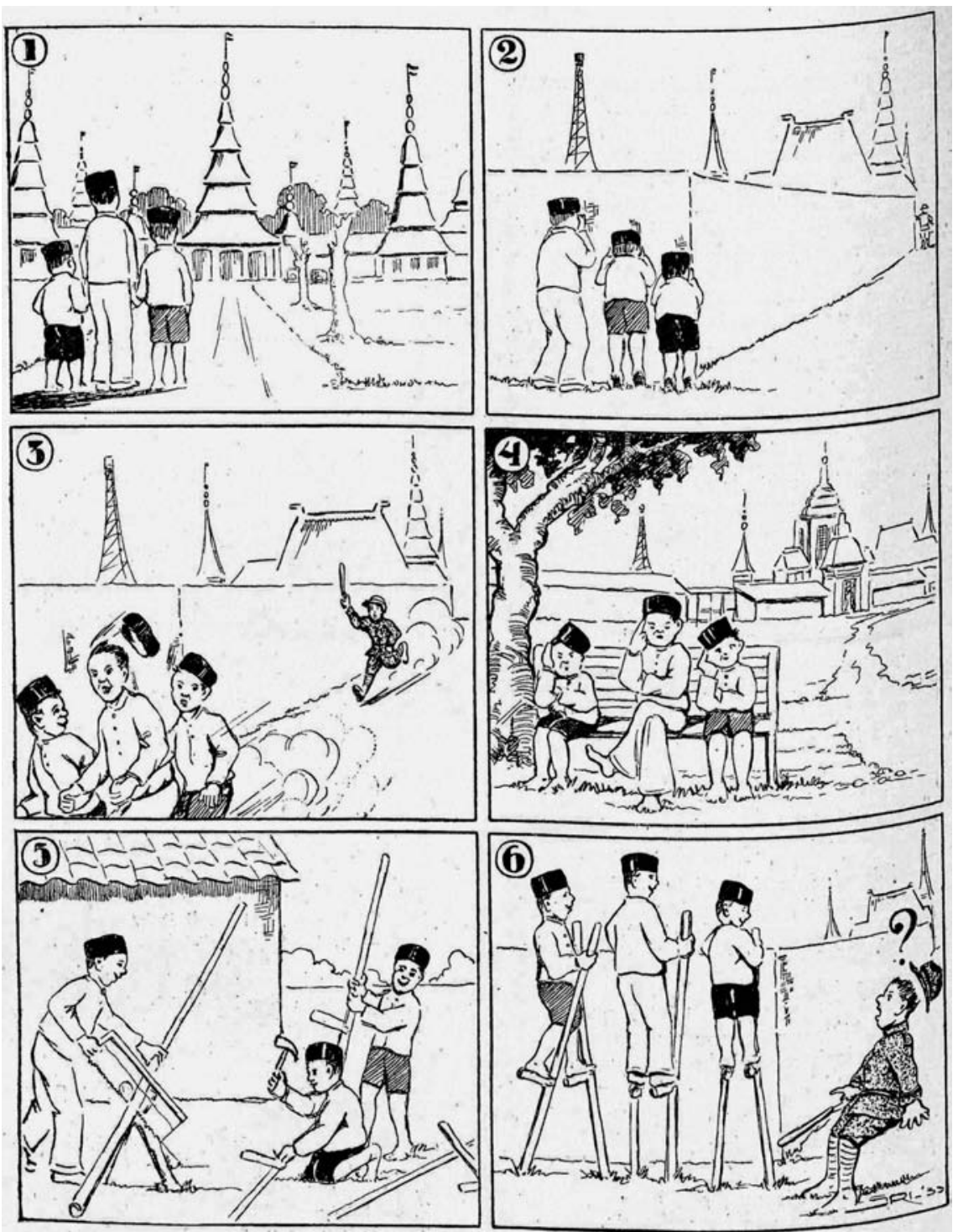

FIGURE 10 'Pasar Gambir: How to watch ... without money' PANDJI POESTAKA, 1-9-1933

The fairs were thus an aspirational experience, and one was always left wanting more. This aspiring feature was reflected in many exhibits, like one on home furnishings at the Pasar Gambir in 1938. Here visitors could observe displays based on income level ( $f_{25}-125$ and $f_{25}{ }^{-}-500$ a month, respectively). According to one observer, the first exhibit was aimed at a broad, middle-class audi- 
ence and drew by far the most attention. Moreover, while lower-middle-class visitors dreamt about the furnishings in the first exhibit, the middle classes themselves marvelled at the more luxurious display. ${ }^{26}$

Taken together, it seems reasonable to assume that the majority of the fairs' indigenous visitors consisted of what Henk Schulte Nordholt and Tom Hoogervorst have described as the nascent lower and 'middle' middle classes (Schulte Nordholt and Hoogervorst this volume). The income level associated with the less expensive display of home furnishings corresponds with the annual income that they have used to estimate the size of the middle classes, which came down to about $5 \%$ of the population of Java and Madura in the 1930s. As they demonstrate, the nascent middle classes can be considered 'children of the colonial state', as they emerged to fill the needs of a modern, colonial economy with comparatively cheap labour. This resulted in a class of mainly white-collar professionals, such as teachers, railroad workers, pawnshop personnel, clerks, and civil servants, who had enjoyed some level of education and whose job security was often tied, directly or indirectly, to the colonial state (Van der Meer 2014:84-94, 189-208). Similarly, the functioning of the colonial state depended on their work. It is therefore not surprising that this was the primary group that the organization behind the fairs had in mind as its intended audience. The fairs were one of the more prolific methods through which the authorities tried to 'sell' colonial modernity as a way to legitimize and strengthen the colonial system. However, this did not mean that the nascent middle classes 'bought' what the Dutch were 'selling'. At the fairs, modernity was not simply imposed upon the indigenous visitors; rather, the fairs were spaces where modernity was contested and negotiated until it became part of a new, autonomous, middle-class culture and lifestyle (Colombijn and Coté 2015:1-28). This process of renegotiation often occurred through commodified performances (Liechty 2003:6-7, 31; Dutton 2012:21-2).

In the discussion of fairs in the colonial and vernacular press the danger of overconsumption and conspicuous spending were recurring themes. The fairgrounds were often described as too tempting for the average visitor, encouraging extravagance and reckless spending. This discussion was not limited to the press; it even reached the floor of the Volksraad (People's Council) several times, especially during the Great Depression, but this never resulted in the cancellation of the fairs (Dijkerman 1927:127). One journalist remarked that the Pasar Gambir should therefore not be considered a volksfeest, a celebration 


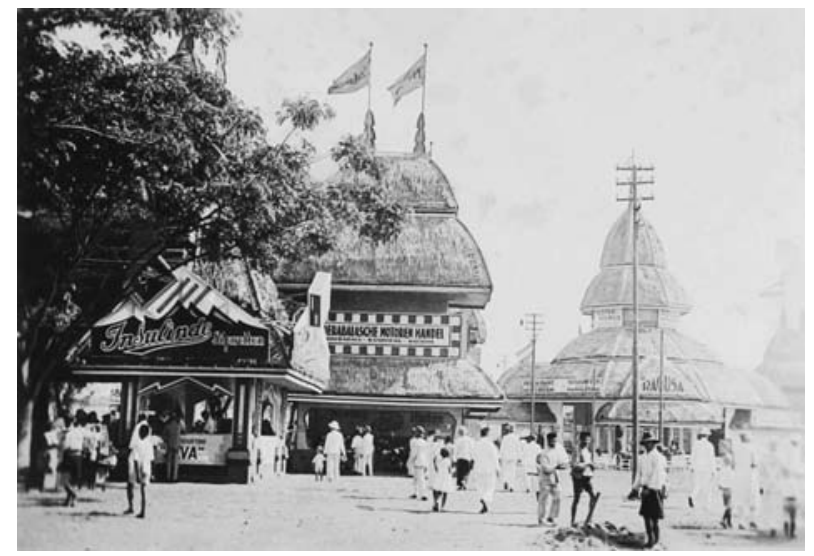

FIGURE 11 Crowds at the Pasar Gambir, 1931 UBL-KITLV 37013

for all people, as the level of engagement depended on one's social position. The fairs' visitors, he argued, could be divided into three classes: the hartawan (wealthy), budiman (wise), and nekat (reckless). The minority of the visitors belonged to the rich who 'swam in money' and could enjoy the fairs to their heart's content. They could attend all performances and dine luxuriously. The wise were also a marginal group, which consisted of people who consumed responsibly and never beyond their means. But the majority of the visitors belonged to the class of the reckless and irresponsible. At the fairs they gave in to their desires and spent conspicuously to impress others by appearing to be wealthy and have a high social status. Ironically, according to the author, their visits to the fairgrounds often ended at the government's pawnshops (Hardjo Soë 1938).

The often-made association between conspicuous spending and colonial fairs suggests that the fairgrounds were spaces where the emerging middle classes actively shaped new identities through consumer culture (Fig. 11). Take the example of Hardjo Soë (a pseudonym meaning 'woe unto me'), a columnist for Pandji Poestaka - very much a middle-class periodical — who described several of his visits to the Pasar Gambir with his spouse. According to Hardjo Soë, he originally belonged to the class of the wise, advocating that they needed to save money to enjoy themselves at Batavia's annual fair. However, his wife did not agree, as she argued that it was important to look good, elegant, and important at the fair; otherwise, people might think that he could not support her, or worse, that she could not run a proper household. Not to be embarrassed, the couple purchased silk voile and brocade clothes for her and gabardine and Palm Beach suits for him. At the cost of accumulated debt, they looked 
neat and elegant and indistinguishable from people with a higher income at the opening of Pasar Gambir (Hardjo Soë 1935a).

Hardjo Soë's recollection illustrated the importance of seeing and being seen at the fairs. This was a space where people experimented with changes in appearance to create new social markers. Hardjo Soë even called people's appearance at the fairs one of its main and most popular exhibits. People's social status was measured by their appearance. According to him, 'in the modern era clothing-styles are manifold' and their meanings could be interpreted in various ways: 'down to earth, unpretentious, brave, slightly elegant, very elegant, modern, and hyper-modern' (Hardjo Soë 1936). The common Javanese visitor still predominantly wore traditional dress, which consisted of a sarong, shirt, and peci (cap), or headscarf for men, and a sarong and kebaya (long blouse) for women. However, the clothing of the majority of visitors might best be described as composite dress, as many people combined certain traditional and modern elements in their appearance. This could range from shoes, trousers, and colourful scarves to walking canes and sunglasses, among others. But it also included cosmetics, like lipstick and foundation, for women. Only those who could afford it and wanted to be considered extremely modern adopted Western dress in its entirety. This meant a suit, shoes, and a hat for men, and a long or short skirt with a modern blouse for women. By the late 193os, most middle-class men had adopted the Western suit in combination with a peci as their appearance, while Javanese women still wore sarong and kabaya, as they were considered the guardians of traditional culture (Taylor 1997, 2007; Van der Meer 2014:169-246).

Without realizing it, Hardjo Soë described the omnipresence of the 'modernized Javanese' at Batavia's fair. While in 1907 the 'modernized Javanese' was out of place at Surabaya's Jaarmarkt, by 1937 the annual fairs had clearly become places where they belonged. One's appearance was only one, albeit the most visual, of the commodified performances which occurred at the fairs. But it was through consumer practices in general that the nascent middle classes created themselves. For instance, for Hardjo Soë wearing a Palm Beach suit did not suffice. Instead of walking or taking a sado (two-wheeled horse-drawn carriage) to the Pasar Gambir, he and his spouse took a taxi. While ownership of cars, powerful symbols of modernity, was still an elite privilege, being able to afford a cab was a significant marker of middle-class status. At the fairgrounds the couple engaged in further conspicuous consumption by visiting the European restaurant. Not to be outdone by the members of the traditional elite, such as civil servants and aristocrats, they pretended to be familiar with the strange dishes and drinks they consumed, including huzarensla (Russian salad), compote, beer, and mineral water. To their shock the food was not very tasty or satisfying, 
but it was rather expensive. Hardjo Soë's anecdote is one of many that illustrate the importance of conspicuous spending at the fairs. But it also provides a clear indication that there was a gender bias in these consumer practices. Throughout his narrative, Hardjo Soë depicts his wife, and women in general, as someone who easily succumbed to consumer impulses. It was because of her concerns about social status that they purchased modern clothing and ate at a fancy restaurant. Moreover, according to Hardjo Soë, she purchased many products at the fairs' exhibits and stands. As with clothing, we can clearly see how establishing a middle-class identity and lifestyle was a gendered issue at the colonial fairs (Hardjo Soë 1935a).

\section{Fairs as Discursive Spaces: Contesting Colonial Modernity}

Contrary to what visitor statistics might suggest, there was considerable scepticism towards the colonial fairs among the Javanese. The main concerns were related to the question for whose benefit these fairs were organized and to what extent they damaged Javanese traditions, culture, and identity. One of the strongest and most eloquent criticisms of annual fairs can be found in an editorial of the biweekly periodical Timboel in October 1928. Published in Surakarta, Timboel was a Javanese, nationalist periodical that openly contested the ongoing Westernization of society. According to the editorial, the modern fairs had not emerged naturally out of the traditional Javanese pasar malam, but were the result of European appropriation of the latter. While the original intent of ethical protagonists had been to promote Java's culture and economy, European business interests had become predominant at the modern fairs. The editors claimed that 'the annual fairs in Surabaya, Bandung, Weltevreden [Batavia], not to mention their local equivalents, increasingly served to advertise and sell European mass-produced commodities.' ${ }^{27}$ They cynically added that indigenous artisans were merely tolerated because of the Europeans' desires to purchase exotic souvenirs. ${ }^{28}$

Gradually, the editorial continued, the Javanese character of the fairs had receded into the background. Javanese artisans could only afford stands on the poorly lit fringes of the fairgrounds, from where they could gape at elaborately decorated stands displaying an abundance of imported commodities basking in electric light. Here the editors invoked and undermined the popular notion

27 'Het jaarmarktwezen', Timboel, 15-8-1928.

28 See, for a similar critique, 'Javaansche cultuurbeweging: Een passer derma', Djawa 4 (1925). 
of the Dutch as enlighteners, arguing that the fairs only benefitted the colonizer, not the colonized. The Europeans' 'desire for conquest' similarly affected the fairs' entertainments. Amoral dancings, carousels, and nude dancers had replaced traditional Javanese gamelan, angklung, and wayang performances. To resist further economic exploitation and cultural degeneration, the editors called for a broad popular reaction against the Western penetration of Javanese culture and society. They believed that through the re-establishment of traditional pasar malam Javanese national identity could be purged from foreign cultural influences.

It is difficult to ascertain how widespread the concerns raised by Timboel's editors were, as the great number of indigenous visitors can easily be interpreted as an indication of an unconditional fascination with the modern fairs. Nonetheless, even the annual coverage of the fairs by Pandji Poestaka, a government periodical aimed at indigenous civil servants, revealed a certain level of ambivalence. Pandji Poestaka, like Timboel, was produced by and for an Indonesian, Western-educated elite whose social position was tied to the colonial order. The articles in these periodicals can best be described as supportive of the civilizing discourse of the colonial government. However, by reading against the grain one can clearly discern anxieties with regard to the fairs within its pages. For instance, throughout the 1920s and 1930s, articles in Pandji Poestaka repeatedly emphasized the various benefits of organizing and attending Java's annual fairs. The apparent need to underscore that the fairs were not merely entertainment, exploitative, or a waste of money, but instead were enlightening experiences that broadened the horizons of their visitors, can be interpreted as an indication that the concerns raised by Timboel's editors were more widespread. The counter argumentation offered by Pandji Poestaka stressed the significance of the fairs for economic progress and development. The exhibits on native arts and crafts, for instance, were not intended for European tourists, but instead meant to stimulate the indigenous industry and instil a sense of cultural pride (Hardjo Soë 1936). Similarly, the pedagogical exhibits of the colonial government were presented as opportunities to learn how to improve one's living conditions (Hardjo Soë 1935, 1937). Instead of interpreting the fairs as exploitative, they were hailed as the driving force behind the movement of people and goods as well as the creation of new commercial markets that facilitated the economic integration of the colony. ${ }^{29}$

If the Pandji Poestaka and the massive visitor numbers are any indication, most visitors were more concerned with cultural and moral degeneration than 
with economic and colonial exploitation. While the fascination with modernity attracted many people to the fairs, it also challenged visitors to consider the effects of this engagement with such events on their identity. The question was, to what extent did modernization, which according to many equalled Westernization, result in a loss of self. This was part of a larger debate within the vernacular press and nascent nationalist movement that was permeated with platitudes, such as the notion that the Javanese should only adopt from the West what is useful, or that the Javanese must reject Western materialism and individualism in favour of Eastern spirituality and collectivism. ${ }^{30}$ The answer to this query depended on one's political outlook; for instance, whether one subscribed to a Javanese-nationalist, Islamic-Reformist, or modern-secular philosophy. Interestingly, it was through a discussion of the consequences of Westernization on indigenous women that the acceptable extent of cultural accommodation and the creation of new identities were determined (Taylor 1997, 2007). In the vernacular press, including the Pandji Poestaka, Westernized indigenous women were often contrasted with a more idealized authentic woman who needed protection from alienating Western influences, which threatened herself, her progeny, and hence the future of the nation. ${ }^{31}$ In 1931 the Persatuan Perkumpulan Isteri Indonesia (Union of Organizations of Indonesian Wives) proclaimed the Indonesian woman as the mother of the nation (Vreede-De Stuers 1960:91). While women through their motherhood came to be defined as guardians of national identity and culture, men were allowed greater liberties in balancing Western influences in their lives (Blackburn 2004: 142-48; Taylor 2007).

Although the negotiation of colonial modernity through gendered concerns about morality was not specific to colonial fairs, they did provide a rather unique discursive space in which new middle-class identities were being shaped. The fairs combined many contentious modern experiences, such as watching movies, listening to music, dancing, sports, conspicuous consumption, and drinking, to name only those most discussed in the popular press. A striking example is the concern about women's clothing at the fairs. The adoption of Western dress was deemed inappropriate for Indonesian women, as it was too revealing and left little too the imagination. ${ }^{32}$ Even the Pandji Poestaka critiqued the manner in which European women dressed at the Pasar Gambir.

30 IPO [Overzicht van de Inlandsche Pers] 1918-48, referring to Sinar Hindia, 30-11-1918; IPO 1920-51, referring to Neratja, 13-12-1920.

31 IPO 1921-3, referring to Oetoesan Hindia, 13-1-1921; IPO 1922-7, referring to Kaoem Moeda, 6-2-1922.

32 IPO 1924-16, referring to Kaoem Moeda, 7-4-1924. 
According to the periodical, parts of European women's bodies were visible for all to see and sorely needed to be covered..$^{33}$ The sensual character of European dress, by virtue of the amount of skin it left exposed and the way it accentuated the feminine form, was considered an affront to Javanese and Islamic traditions alike. ${ }^{34}$ This did not mean that Indonesian women did not experiment with European or modern dress; however, by the late 1920s and 1930s, this occurred by wearing non-traditional, colourful clothing items, like scarves or blouses, in combination with the more traditional sarong. While even this drew some ridicule in the vernacular press, for instance in the Pandji Poestaka, where these composite styles were likened to fireworks, they did not draw the fierce criticism that European dresses and skirts did (Hardjo Soë 1937).

Unsurprisingly, the experimentation with more cosmopolitan social norms at the fairs received copious amounts of attention in the vernacular press. Compared to traditional Javanese society, where interaction between men and women was circumscribed, the fairs were public spaces where the sexes mingled relatively freely. Adolescents demanded the right to socialize with their friends, of both genders. At the fairs they often went out unsupervised, walked arm in arm, shook hands, kissed, practised European dances, visited the movie theatre, a musical performance, or simply a carnival ride. ${ }^{35}$ European dances, which implied dancing with a single partner of the opposite sex, were especially criticized for arousing the excitement of the participants. ${ }^{36}$ This was considered particularly inappropriate for young women, who ran the risk of losing their 'innocence'. The aforementioned correspondent of the Pandji Poestaka, Hardjo Soë, described how he found this modern activity indecent, shameful, and embarrassing (Hardjo Soë 1935). Others contrasted European dancing with the traditional Javanese dances, which never 'degenerated into the unbecoming embrace between men and women'. ${ }^{37}$ Alternatively, traditional Javanese dances were imagined as performances to be observed, not to engage in.

Instead of uncritically engaging with, or even buying into, colonial modernity and discourse, the indigenous visitors of Java's fairs contested those elements that did not conform to their cultural or moral beliefs and sense of self. This does not mean that visitors were not fascinated with the display of modernity at the fairgrounds, but it illustrates there were considerable limitations to

\footnotetext{
33 'Berdjalan-djalan ke Pasar Gambir', Pandji Poestaka, 4-9-1924.

34 IPO 1926-24, referring to Pantjadjania, 21-5-1926.

35 IPO 1920-6, referring to Djawa Tengah, 5-1-1920.

36 IPO 1921-4, referring to Boedi Oetomo, 19-1-1921; IPO 1924-36, referring to Persamaan, 2O8-1924.

IPO 1925-6, referring to Darmo Kondo, 28-1-1925.
} 
the extent of its adoption. Taken together, the commodified consumer performances and the moral negotiation of modernity resulted in the formation of a new, albeit fluid, modern, middle-class identity and lifestyle that was particularly suited to the Indonesian context (compare Joshi 20o1). While the fairs were merely one of the stages on which this modernity was fashioned and performed, due to their sheer size and reach they were among the more prominent discursive spaces in the late-colonial world.

\section{References}

Abendanon, J.H. (1904). Rapport van den directeur van onderwijs, eeredienst en nijverheid betreffende de maatregelen in het belang van de inlandsche nijverheid op Java en Madoera in verband met de door het moederland voor dit doel beschikbaar te stellen fondsen. Batavia: Landsdrukkerij.

Blackburn, S. (2004). Women and the State in Modern Indonesia. Cambridge: Cambridge University Press.

Bloembergen, M. (2006). Colonial spectacles: The Netherlands and the Dutch East Indies at the world exhibitions, 1880-1931. Singapore: Singapore University Press.

Burke, T. (2012). 'Unexpected subversions: Modern colonialism, globalization, and commodity culture', in: F. Trentmann (ed.), The Oxford handbook of the history of consumption, pp. 468-74. Oxford: Oxford University Press.

Cohen, M.I. (2016). Inventing the performing arts: Modernity and tradition in colonial Indonesia. Honolulu: University of Hawai'i Press.

Colombijn, Freek and Joost Coté (2015). 'Modernization of the Indonesian city, 1920196o', in: Freek Colombijn and Joost Coté (eds), Cars, conduits, and kampongs: The modernization of the Indonesian city, 1920-1960, pp. 1-28. Leiden: Brill.

Coté, J. (2000). ' "To see is to know": The pedagogy of the colonial exhibition, Semarang, 1914', Paedagogica Historica 36-1:340-66.

Coté, J. (2006). 'Staging modernity: The Semarang international colonial exhibition, 1914', Review of Indonesian and Malaysian Affairs 40-1:1-44.

Cox, H. (200o). The global cigarette: Origins and evolution of British American tobacco, 1880-1945. New York: Oxford University Press.

De Pasar Gambir (1932). De Pasar Gambir. N.p.: De Unie.

Dick, H. (2002). The emergence of a national economy. Sydney: Allen \& Unwin.

Dijk, K. van (2007). The Netherlands Indies and the Great War, 1914-1918. Leiden: Brill.

Dijkerman, G.J. (1927). 'Het jaarmarktwezen in Nederlandsch-Indië', Koloniale Studiën 11-2:121-52.

Doorn, J.A.A. van (1994). De laatste eeuw van Indië: Ontwikkeling en ondergang van een koloniaal project. Amsterdam: Bakker. 
Dutton, G. (2012). 'Advertising, modernity, and consumer culture in colonial Vietnam', in: V. Nguyen-Marshall, L.B.W. Drummond, and D. Bélanger (eds), The reinvention of distinction: Modernity and the middle class in urban Vietnam, pp. 21-42. Dordrecht and New York: Springer.

Eng, P. van der (1992). 'The real domestic product of Indonesia, 1880-1989', Explorations in Economic History 29:366-70.

Gramsci, Antonio (1971). Selections from the prison notebooks, edited and translated by Quintin Hoare and Geoffrey Nowell Smith. New York: International Publishers.

Hardjo Soë (1935a). 'Omong kosong: Pasar Gambir', Pandji Poestaka 13-70: 1355-56.

Hardjo Soë (1935b). 'Omong kosong: Pemandangan dalam Pasar Gambir', Pandji Poestaka 13-72:1394-96.

Hardjo Soë (1936). 'Omong kosong: Pasar Gambir di Betawi', Pandji Poestaka 14-71:138486.

Hardjo Soë (1937). 'Omong kosong: Pemandangan Pasar Gambir', Pandji Poestaka 1575 .

Hardjo Soë (1938). 'Omong kosong: Pemandangan tentang Pasar Gambir', Pandji Poestaka 16-70, 71, and 72:1367-68.

Houben, V. (2008). 'Representations of modernity in colonial Indonesia', in: M. Schrempf and V. Houben (eds), Figurations of modernity: Global and local representations in comparative perspective, pp. 23-40. Frankfurt: Campus Verlag.

Indisch Verslag (1931). Indisch Verslag 1931. I. Tekst van het verslag van bestuur en staat van Nederlandsch-Indië over het jaar 1930. The Hague: Landsdrukkerij.

Jaarverslag (1929-1934). Jaarverslag Nederlandsch-Indische Jaarbeurs te Bandoeng. Tegal etc: De Boer.

Jasper, J.E. (1906). Verslag van de eerste tentoonstelling-jaarmarkt te Soerabaja. Batavia: Landsdrukkerij.

Jasper, J.E. (1909). Verslag van de vierde tentoonstelling-jaarmarkt te Soerabaja. Semarang: G.C.T. van Dorp \& Co.

Jasper, J.E. (1911). Verslag van de eerste Semarangsche jaarmarkt-tentoonstelling, 1908. Batavia: Landsdrukkerij.

Jasper, J.E. (1924). De organisatie van een jaarmarkt-tentoonstelling: De 2 e te Pekalongan. Tegal: De Boer.

Joshi, S. (2001). Fractured modernity: Making of a middle class in colonial north India. New Delhi: Oxford University Press.

Kelling, M.A.J. (1925). 'Het jaarbeurswezen in Nederlandsch-Indië', Koloniale Studiën 92:210-42.

Kelling, M.A.J. (1927). ‘De Eerste Hygiëne-Tentoonstelling in Nederlandsch-Indië', D’Oriënt 6-27:63-64.

Keppy, P. (2008). 'Keroncong, concours, and crooners: Home grown entertainment in early twentieth-century Batavia', in: P. Boomgaard, D. Kooiman, and H. Schulte 
Nordholt (eds), Linking destinies trade, towns and kin in Asian history, pp. 141-57. Leiden: Brill.

Liechty, M. (2003). Suitably modern: Making middle-class culture in a new consumer society. Princeton, NJ: Princeton University Press.

Locher-Scholten, E. (1981). Ethiek in fragmenten: Vijf studies over koloniaal denken en doen van Nederlanders in de Indonesische archipel, 1877-1942. Utrecht: Hes.

Low, Setha M. (200o). On the plaza: The politics of public space and culture. Austin: University of Texas Press.

Lukito, Yulia Nurliani (2015). 'Colonial exhibition and a laboratory of modernity: Hybrid architecture at Batavia's Pasar Gambir', Indonesia 100:77-103.

Lukito, Yulia Nurliani (2016). Exhibiting modernity and Indonesian vernacular architecture: Hybrid architecture at Pasar Gambir of Batavia, the 1931 Paris International Colonial Exhibition and Taman Mini Indonesia Indah. Wiesbaden: Springer vs.

Meer, A.H.C. van der (2014). Ambivalent hegemony: Culture and power in late colonial Java, 1808-1927. [PhD thesis, Rutgers University].

Miert, H. van (1991). Bevlogenheid en onvermogen: Mr.J.H. Abendanon (1852-1925) en de ethische richting in het Nederlandse kolonialisme. Leiden: KITLV.

Morton, P.A. (2000). Hybrid modernities: Architecture and representation at the 1931 colonial exposition, Paris. Cambridge, MA: MIT Press.

Niel, R. van (1984). The emergence of the modern Indonesian elite. Leiden: Foris.

Onderzoek (1909). Onderzoek naar de oorzaken van de mindere welvaart der inlandsche bevolking op Java en Madoera. VIa: Overzicht van de uitkomsten der gewestelijke onderzoekingen naar den inlandschen handel en nijverheid en daaruit gemaakte gevolgtrekkingen. Batavia: Van Dorp.

Onderzoek (1911). Onderzoek naar de oorzaken van de mindere welvaart der inlandsche bevolking op Java en Madoera. IXa: Overzicht van de uitkomsten der gewestelijke onderzoekingen naar de economie van de desa en daaruit gemaakte gevolgtrekkingen. Deel I: Eigenlijk overzicht van de samentrekkingen der afdeelingsverslagen (19041906). Batavia: Kolff.

Onderzoek (1914). Onderzoek naar de oorzaken van de mindere welvaart der inlandsche bevolking op Java en Madoera. XI: Voorstellen en besluiten der Welvaartkommissie in 1914. Batavia: Papyrus.

Pleyte, C.M. (1907). Verslag nopens de Pasar-Gambir: Gehouden op het Koningsplein te Weltevreden van 18 Augustus-2 September 1906. Batavia: Landsdrukkerij.

Programma (1922-1933). Programma van den Pasar Gambir. Batavia: Pasar Gambir Comité.

Reitsma, S.A. (1927). 'Bandoeng en de Jaarbeurs', D'Oriënt 6-26: 55-58.

Rydell, R.W. (1984). All the world's a fair: Visions of Empire at American international expositions, 1876-1916. Chicago: University of Chicago Press.

Schulte Nordholt, H. (2011). 'Modernity and cultural citizenship in the Netherlands Indies: An illustrated hypothesis', Journal of Southeast Asian Studies 42-3:435-57. 
Schulte Nordholt, H. (2015). 'Modernity and middle classes in the Netherlands Indies: Cultivating cultural citizenship', in: S. Protschky (ed.), Photography, modernity and the governed in late-colonial Indonesia, pp. 223-54. Amsterdam: Amsterdam University Press.

Shiraishi, T. (1990). An age in motion: Popular radicalism in Java, 1912-1926. Ithaca: Cornell University Press.

Simon Thomas, A.E. (1928). De importeur, de Pasar Gambir, Jaarbeurs, pasar malem en jaarmarkten. Soerabaia: Hahn.

Simon Thomas, A.E. (1929). Een en ander over de plaats der jaarmarkten in de Indische maatchappij: Prae-advies uitgebracht op de jaarvergadering der Vereeniging tot bevordering van het jaarmarktwezen in Nederlandsch-Indië, gehouden te Soerabaja op 13 October 1929. Weltevreden: Emmink.

Soerabaiasche jaarmarkt (1924-1931). Programma van de Soerabaiasche jaarmarkt vereeniging. Surabaya.

Taylor, J.G. (1997). 'Costume and gender in colonial Java, 1800-1940', in: H. Schulte Nordholt (ed.), Outward appearances: Dressing state and society in Indonesia, pp. 85116. Leiden: KITLV Press.

Taylor, J.G. (2007). ‘Identity, nation and Islam: A dialogue about men's and women's dress in Indonesia', in: M. Roces and L.P. Edwards (eds), The politics of dress in Asia and the Americas, pp. 101-20. Brighton and Portland: Sussex Academic Press.

Vreede-De Stuers, C. (1960). The Indonesian woman: Struggles and achievements. The Hague: Mouton \& Co.

Wall, V.I. van de (1924). 'Pasar Gambir voor honderd jaren', D’Oriënt 3-35:12. 